University of Louisville

ThinkIR: The University of Louisville's Institutional Repository

$12-1946$

\title{
A study in elementary schools in 1946 of twenty-six children who attended Mental Hygiene Clinic Nursery School, Louisville, Kentucky in 1939-1942.
}

Ann Coleman

University of Louisville

Follow this and additional works at: https://ir.library.louisville.edu/etd

Part of the Social Work Commons

\section{Recommended Citation}

Coleman, Ann, "A study in elementary schools in 1946 of twenty-six children who attended Mental Hygiene Clinic Nursery School, Louisville, Kentucky in 1939-1942." (1946). Electronic Theses and Dissertations. Paper 1892.

https://doi.org/10.18297/etd/1892

This Master's Thesis is brought to you for free and open access by ThinkIR: The University of Louisville's Institutional Repository. It has been accepted for inclusion in Electronic Theses and Dissertations by an authorized administrator of ThinkIR: The University of Louisville's Institutional Repository. This title appears here courtesy of the author, who has retained all other copyrights. For more information, please contact thinkir@louisville.edu. 
UNIVERSITY OF LOUISVILEE

\begin{abstract}
A STUDY IN ELENENTARY SCHOOLS IN 1946
OF TWENTY-SIX CHILDREN WHO ATTENDED

MENTAL HYGIENE CLINIC NURSERY SCHOOL,

LOUISVILLE, KENTUCKY

IN $1939-1942$
\end{abstract}

\author{
A Dissertation \\ Submitted to the Faculty \\ Of the Graduate School of the University of Louisville \\ In Partial Fulfillment of the \\ Requirements for the Degree \\ of Master of Science in Social Work
}

Raymond A. Kent School of Social Work

By

Ann Coleman

Year

1946 
NANE OF STUDENT: Ann Colemen

TITLE OF THESIS: A Study in Elementary schools in 1946 of Twenty-Six Children Who Attended Mental Hygiene Clinic Nur sery School, Louisville, Kentucky in 1939-1942

APPROVED BY THE READING COMMITTLE CONPOSED

OF THE FOLLOWING WERBERS:

NALE OF DIRECTOR: John J. Cronin

DATE: Dee. 17, 1946 


\section{ACKNOWLEDGEUENT}

The writer wishes to acknowledge her Eratitude to úr. John J. Cronin for his direction and assistance in the preparation of this material; to the staff of the Loulsvilie Wental Hygiene Clinic for their cooperation in placing material at her disposal, especially Dr. Arthur Benton, Psychologist and Miss Mary Monk, Director of the Child Study Nursery School. 
IIST OF TABLES. • • . . . . . - . . . . . .

INTRODUCTION. . . . . . . . . . . . . . . . . iii

CHAPTER

I. THE IOUISVIELE HENIAL HYGIENE CLINIC

NURSERY SCHOOL. .........

II. METHOD OF STUDY. . . . . . . . . . . . 5

Data From Nursery School Record. . . . 7

Classification of Children From Nursery

School Records. . . . . . . . . . 8

Data From Elementary School in 1946. . . 18

Classification of Children From Interview with Elementary School Teachers. . . . 19

III. HONE SITUATIONS OF CHILDREN. • • • • • • 25

Social Service Exchange Registration of Families . . . . . . . . . . . 25 Marital Status of Parents......... 27 Socio-Economic Ievel of Parents... . . 28 Other Features in the Home Situations. . 31 Evaluation of the Home by Elementary School Teacher............... 34

IV. CHARACTERISTICS OF CHIIDREN. . . . . . . 37

Age of Children. . ........... 37 Sex of Children.............. 38 Position in Family Group . . . . . . . 41 Physical Condition............. 42 IQ of the Children........... 44 School Achievement..... . . . . . 48 Term of Stay .......... . . . . . 49

V. BEHAVIOR OF THE CHIIDREN . . . . . . . 52

Relationship with Other Children... . 52 Types of Problems. . . . . . . . 54 SUMLART . . . . . . . . . . . . . . . . 63

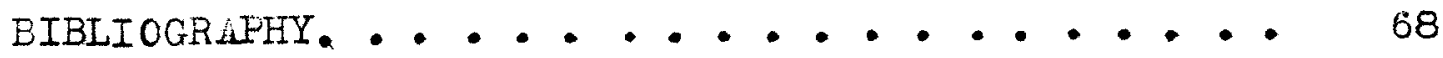
APFENDIX. . . . . . . . . . . . . . . . . 71 


\section{LIST OF TABLES}

Table

Page

1. Status of Sixty-Seven Children Attending Nursery School During the School Years 1939-1942 at the Time of the Follow-Up

Study in May-June, 1946. . . . . . . . .

2. Number of Initial Problems and Improvement of Twenty-Six Children Attending Nursery

School, 1939-1942 ...............

3. Number of Problems of Twenty-Six Children

in Elementary Schools, May-June, 1946. . . 20

4. Adjustment of Twenty-Six ChIldren

Elementary Schools, 1946, According to

Degree of Improvement in Nursery School. . . 24

5. Social Service Registration on the Families

of Twenty-Six Chilaren in Element ary

Schools, October, 1946...... . . . 26

6. Marital Status of Parents of Twenty-Six

Children Attending Nursery School, 1939-1942. 28

7. Socio-Economic Level of the Parents of

Twenty-Six Children Attending Nursery

School, 1939-1942............. 29

8. Socio-Economic Level of Twenty-Six Chilaren

by Types of Problems............ 30

9. Evaluation of the Home Situation of Twenty-

Six Nursery School Children at Time of the

Follow-Up Study, According to their Ele-

mentary School Adjustment . . . . . . 36

10. Age at Entrance of Twenty-Six Chilaren Attend-

ing Nursery School, 1939-1942, By Sex . • . 38

11. Sex of Twenty-Six Children in Elementary

School By Types of Problems. . . . . . 40 


\section{LIST OF TABLES}

Table

Page

12. Position in Family Group of Twenty-Six Chilaren Attending Nursery School, $1939-1942$. . . . . . . . . . . . 41

13. Physical Condition of Twenty-Six Children Attending Nursery School According to Adjustment There and in Elementary Schools, 1946 .................. 43

14. IQ's of Twenty-Six Children in Nursery Sch001, 1959-1942. . . . . . . . . 45

15. IQ of Twenty-Six Children in Elementary School By Types of Problems......... 46

16. School Achievement of Twenty-Six Children in Elementary School, 1946. . . . . . . 49

17. Term of Stay of Twenty-Six Children in Nursery School, 1939-1942 . . . . . . 50

18. Relationship With Other Children of TwentySix Children According to Nursery School Attendance, 1939-1942, and Elementary

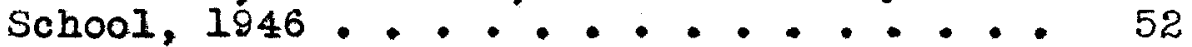

19. Types of Problems of Twenty-Six Children Attending Nursery School, 1939-1942 . . . 56

20. Types of Problems of Twenty-Six Children in Elementary Schools, May-June, 1946 . . 57

21. Types of Behavior of Twenty-SIx Children in Nur sery School, 1939-1942, and in Elementary School, 1946 
INTRODUCTION 


\section{INTRODUCTION}

This study is an attempt to follow the development of the group of children who attended the Mental Hygiene Clinic Nursery School of Louisville, Kentucky in its first three years, september, 1939 through May, 1942. The children were studied on a comparative basis of their behavior in the two school situations - nursery school in 1939-1942 and element ary school in 1946. The study not only considers the child's behavior in the classroom, but also attempts to evaluate the effects of personality and environmental inIluences upon the child's school adjustment - his health, conditions in the home, and mental development.

The preschool years are now being recognized as of more developmental importance than any succeding periad of life. The White House Conference reports after a careful survey, "In early childhood - even as early as four years of age - about one-third of apparently normal children of self-sustaining families, average in intelligence have behavior problems sufficiently marked to necessitate treatment. Large numbers of children still need help at the kindergarten and primary levels. "I

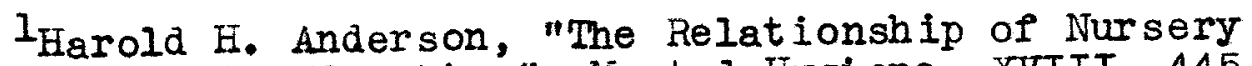
Schools to Public Education", Mental Hygiene, XVIII, 445. 
"The Nursery School is the educational answer that this generation is making in order to provide an environment where young children two to five can develop to their furlest extent." 1

As we had no contact with the home of the children in 1946, we could not attempt to make an evaluation of the effect of the nursery school program on the children. We do attempt to compare the children's behavior in elementary schools in 1946 as evaluated by interviews with the ir teachers over against the children's behavior in nursery school as it was recorded in 1939-1942.

The lack of objectivity is a blg factor in our method fram the standpoint of (I) the personal reactions of the teacher will doubtlessly color her evaluation of the child, and (2) the evaluation of the child's behavior at nursery school was dependent upon the writer's interpretation of the recorded data, which also has the dangers of being subjective. Howerer, in spite of these disadvantages in the method of study, it is hoped that we may find some interesting correlations that might prove worthy of further study.

"We are aware that education and mental hygiene have involved different goals - education seeking to make the individual conform to a group pattern, while mental hygiene aims to nurture an individual in terms of his own

$$
\text { 1Mrs. A. B. Sawyer, Jr., "The Nursery School", }
$$
Louisville, Ky., September, 1939. (Mimeag raphed) 
personal satisfactions."I we are also aware that the child's behavior in school cannot be considered apart from his behavior at home or from effects of physical condition, or from IQ.

It is realized that the group studied is too small to reach any definite conclusions - only 40 per cent of the total number of children attending nursery school in 1939-1942 were located in elementary schools in 1946. Again, we say that we hope it will show trends or correlations from which definite conclusions could be reached upon further investigation.

There is at the very outset a difficulty in a study consisting of an evaluation of behavior with respect to how desirable or undesirable it may be. No one could make such distinctions on the basis of factual knowledge or draw up a list of behavior problems of children to which any other individual would entirely agree. 2

There have been several studies of a somewhat similar nature to the present study; the main difference is that most of these other studies had a control group for comparison with the group studied: Children's Behavior and Teachers' Attitudeg by E. K. Wickman, Educational Achievement of Problem Children by Paynter and Blanchard, A Comparative Study of a Nursery School Versus a Non-Nursery School Group by

Ira S. Wile, "Integration of the Child the Goal of the Educat Ional Program", Mental Hrgiene, (1936), XX, 249. 2E.K, Wickman, Children's Behavior and Teaghers'
Attitudes, 
Ethel Kawin, and Children's Beharlor Problems by Luton Ackerson. This study has no control group; it differs from these others in that it studies the same group in two different situations.

Gain and loss in this study are measured in terms of group averages and group tendencies rather than in terms of what has happened to the individual child as a personality. What are needed are uniform studies yielaing data on large numbers of children and more reliable instruments of measurement with which to measure possible differences in development between children who attend nursery schools and children who do not. What are especlally lacking are valid and reliable instruments with which to measure such physical conditions, personality traits, types of behavior, and levels of habit training as are generally recognized as acknowledged objectives of nursery-school education." 1

Ethel Kawin continues with the above statement by saying that "every added study, however, may prove a contribution toward the accumulation of data which may in $t$ ime throw some light on this very complex problem."2 This study, then, is presented as another link in such a chain.

IEthel Kawtn and Carolyn Hoefer, A Comparative study of a Nursery School Ver sus a Non-Nursery School Group, TChicago: The University of Chicago Press, 1931), p. 4. 


\section{CHAPTER I}

THE LOUISVILIE MENTAL HYGIDNE CLINIC NURSERY SCHOOL 


\section{CHAPTER I}

THE IOUISVILIE WENTAL HYGIENE CLINIC NURSERY SCHOOL

The Louisville Mental Hygiene Clinic established a nursery school in August, 1939 for the observation and treatment of young problem children. This program was set up as an experiment for a three-year period under the sponsorship of the Younger Woman's Club of Louisville, the Community Chest, and the University of Louisville.

The two-fold purpose of this new experiment was the guidance of children during their most formative years and a demonstration to parents, doctors, student nurses, social workers, and the community at large of the best methods of training young children. ${ }^{1}$ The Nursery School was described as "a planned environment indoors and out-of-doors, where pre-school children can begin to learn the art of successful living through play, - the child's form of work-, under teachers trained in the techniques of handing them in these early years. Here they develop habits of friendliness, habits of work and order, habits of sleeping, and habits of

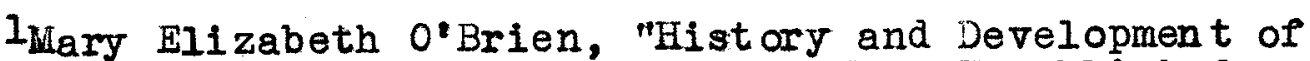
the kental Hygiene Clinic", Louisville, Ky., Unpubli shed Miaster's Thesis, Graduate Division of Social Administration, University of Louisville, 1944. 
eating that will make them adequate physically and emotionally." 1

Normal children, aged two to five years, with behavior problems were admitted to the school. The child's mother was "expected to cooperate actively by observing the work at the school, consulting with the clinic stafr, and attend Ing a wekly child guidance lecture for mothers."2 The Nursery School opened at 8:30 A.N. and closed at 2:00 P.M. Monday through Friday; it inc Iuded indoor and outdoor periods of wark and play, music and rhythms, stories and discussion, rest, dinner and a two-hour nap.

In the first year of the liental Hygie ne Clinic Nursery School, September, 1939 - May, 1940, children were accepted on a control-study basis. It was found after the children were enrolled in school that this basis was not valid; the control children, al though referred by parents as showing no problems, were found to have as many or more problems than the study group. This classification was discontinued in the second year group of children.

A follow-up study was made by a psychiatric social worker in the home and school of the child each year after his attendance at Nursery School. The children in the first

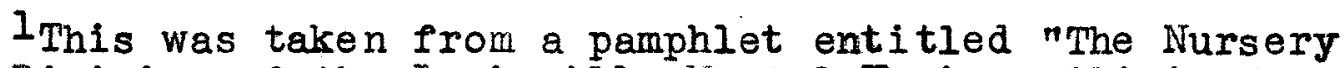
School Division of the Louisville Mental Hygiene Clinic," Louisville, Ky., October 5, 1942 .

2Ib1d. 
two year groups were studied twice in a follow-up. The studies were made to follow-up the development of the individual children, and also, to evaluate the effect of the Nursery school program. I

In follow-up studies of the first year group, it was found that while the majority of these children maintained improvement in kindergarten and first grade, in general the fundamental parent-child relationship had not shown as much improvement as was desired by the clinic staff. Therefore, in the second year of the school, September, 1940 - May, 1941, it was decided to adopt the policy of not accepting children in the Nursery School unless the parents were willing to participate actively in the treatment. Consequently, each parent was seen in the Clinic for individual interviews on the parent-child relationship.

In September, 1942, the Louisville Community Chest asked the Health Council to form a committee which would evaluate the work of the liental Hygie ne Clinic Nursery School The comittee considered the program of the school and the school's place in the community and made the following conclusions: ${ }^{3}$

$I_{A}$ summary of the follow-up studies con be found in Appendix A.

2 This comittee was made up of eight non-staff menbers of Mental Hygiene Clinic. It included interested lay persons in the community and representatives from health and social agencies.

3Louisville Health Council, "Report on the Mental Hygiene Clinlc Nursery School, Louisville, Ky.", October 5, 1942. (Mimeographed) 
1. The Nur sery School should be continued.

2. The Nental Hygiene Clinic Nursery School fills a need in the community which is not met by any other agency, in training doctors, nurses, teachers, parents, and others how to deal with behavior problems in pre-school children.

3. It renders guidance to both children and parents to forestall and prevent more serious problems developing at a later date.

4. The Nursery School is conducted for research and demonstration and meintains high standards in many respects, but is handicapped by lack of adequate physical facilities.

On the basis of the Health Council report, the Louisville Community Chest agreed to continue its support of the Nursery School. The Younger Homan's Club withdrew its funds at the end of the three-year demonstration period as the demonstration had been effective in proving the need of the nursery school program in the comnunity.

In February, 1944, the Nursery School was discontinued during the clinic's search for more adequate quarters and a full-time director for the school. Warch, 1945, the school again opened as the present "Child Study Nursery School" supported by tuition, Community Chest funds, a Special Fund of the University of Louisville, and donations from private clubs. Although, the Child Study School now has its own full-time director, the liental Hygiene clinic continues to have responsibility for the establishment of aims and policies $f$ or the school. 
CHAPTER II

METHOD OF STUDY 
CHAPTER II

\section{METHOD OF STUDY}

The group selected for study were children who attended the Wental Hygiene Clinic Nursery School for the first three years of the school, September, 1939 through May, 1942. There was a total of sixty-seven children attending Nursery School during this period.l

The location of the children in the follow-up study in May-June, 1946 was determined through the use of the files of the Census Bureau of the Louisville Board of Education and the Jefferson County Board of Education. Since the school census is continuous, it showed the grade and school of each child if he had ever been entered in a school; if removed, the cause of removal was given - whether he moved from the city or county, transferred to another school in the city or county, or was removed from school entirely far reasons of health.

$I_{A}$ variance in the total number of children attending Nursery School during these three years was found in the follow-up studies made by Mental Hygiene Clinic. In one place, a total of 79 children was used, and in another, 76 . By checking over the intake book for the first three years of the school, 78 children were found who entered the school. Eleven of the se were entered in school for more than one year and were re-caunted in the total, leaving 67 as the actual number of children attending Nursery school for the first three years. 
The children chosen for the follow-up study had (1) attended the Nursery School for at least a month within the period september, 1939 through May, 1942l, and were (2) attending a school in Louisville or Jefferson County at the time of the follow-up in May-June, 1946.

As shown in Table I, twenty-six children, or approximately 40 per cent of the 67 children were found that met the above requirements. The remaining 41 children failed to meet these requirements because of the following reasons: (1) twenty had moved out of the city or county, (2) ten were patients at the Children's Free Hospital at the time of attendance in Nursery School and returned to their homes out in the state after di scharge from the hospital, (3) seven attended Nursery School less than a month, (4) three were not located in the school census files which probably meant that the family had moved out of the city or county before the child reached school age, and (5) one child was confined in a state mental hospital.

\section{TABLE 1}

STATUS OF SIXTY-SEVEN CHILDREN ATTENDING NURSERY SCHOOL DURING THE SCHOOL YEARS 1939-1942 AT THE TIME OF THE FOILON-EIP STUDY IN MAY-JUNE, 1946

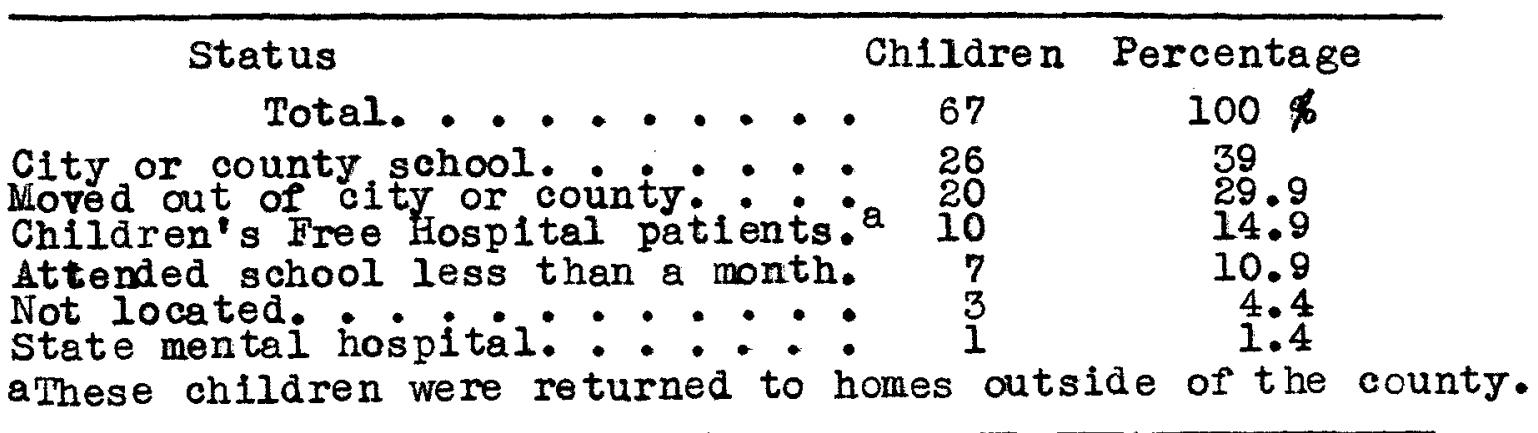

$1_{\text {As }}$ it was felt that the child could have benefitted little from the nursery school experience in less than a month's time, these children were not included in the study. 
Data From Nursery School Records

The Nursery School records contained (I) a referral summary giving family history and the physical, mental and emotional development of the child, (2) running records of psychiatric or sociel work interviews with the mother and the child, (3) reports of psychological tests - the children were tested when they entered and usually given a re-test at the end of the nursery school year, (4) daily observation notes on the performance of the children in school, (5) a closing evaluation of the children in Nursery school, (6) a closing summary evaluating the effect of the clinic contact on the mother's and child's problems, and (7) follow-up studies made by social workers to the home and school of the child a year after attendance in Nursery school. 1

The referral summary varied in the volume of information obtained - depending on the source. In some cases, the mother came into clinic for a referral interview with a psychiatric social worker, and in other cases, the material was obtained from a social agency or some other referral source.

In some instances, there was very little material in the record about the parent-child relationship, the problems of the parent, or any features in the home situation affecting the child's behavior. This was due to the fact

IThe schedule used in gathering Nursery school data can be found in Appendix $\mathrm{t}_{\text {, }}$ gathering Nursery school data 
that not all mothers and not all children held regular interviews with the social worker or psychiatrist. The tendency seemed to be for the clinic to have little or no contact with mothers of the control children, although this was not al ways true.

Another distinction between the control and study children seemed to be that many of the control children's records did not contain daily observation records. Only an evaluative statement of the child's performance for the year was recorded.

Due to this lack of uniformity of recorded data, the information about one child and his family might be voluminous, as compared with another child about whom very little was known.

Classification of Children From liursery School Records

It was found helpful for study purposes, to classify the children in to three groups according to the degree of improvement resulting from their nursery school experience. Improvement as it is used here does not refer to improvement of the child in nursery school environment alone. It refers to the whole development of the child as shown by his ability to meet and adapt to all life situations his relations in the home, his relations with other children in the neighborhood, and his relations with other adults. When he left the nursery school environment, did 
he continue to present eating and sleeping difficulties? How does he get along with his parents, siblings, and other children? What sort of work and play habits has he formed?

The basis for evaluation of improvement in the child was the opinions of (1) the nursery school teacher, (2) members of the clinic staff, (3) the parents, and (4) followup studies a year after the child's attendance at Nursery School.

It would be difficult to say how much improvement was due to the child's nursery school experience, excluding the influence of other environmental factors. The degree of improvement refers to the amount of change observed in the individual child during the period of his attendance at Nursery School. Consideration is given to such factors as low IQ and poor health of the child; blockage due to problems of the parents; and low economic level of the family.

Group One consists of twelve children who showed a marked degree of improrement in Nursery School. Group Two, seven children, showed little or no improvement; and Group Three, seven children, was a classificati on where improvement was not clearly defined.

The sum of the inftial problems and the sum of the problems improved in each of the three groups was obtained in an attempt to judge the amount of improvement. This procedure brought out that Group I, twelve children, 
presented a total of seventy-seven problems of which sixty-eight, or 89 per cent were improved. Graip II, seven children, presented a total of sixty-four problems with thirty-four, or 53 per cent improved. Group III, seven children, presented a total of thirty-five problems and twenty-eight, or 80 per cent were improved.

Table 2 shows the number of problems and their improvement for the three groups of children. Table 19, infra, page 56 lists the types of problems. These figures are a rough estimate, and are used only because they help to visualize the degree of improvement in the three groups. A problem might have existed, and not been recorded because it was unimportant in one worker's viewpoint. The same problem would be recorded as playing an important part in a child's behavior by a different worker. In the same manner, a problem might have shown improvement, yet not been recorded. Then, too, from the recorded data, it is impossible to judge the intensity of the problem as it occurs in the different children.

The difficulties involved make us question the validity of any such classification. Yet, this seemed to be the best method of evaluating the adjustment of these children in 1946 as the control-study group set up in Nursery School in 1939 could not be used. ${ }^{1}$ By using this 
classification, we can compare the school adjustments of the children on whom the nursery school program was thought to show some effect with those children on whom the prof ram was thought to show little or doubtful effect.

TABLE 2

NUMBER OF INITIAL PROBLENS AND INLROVEMENT OF TUENTY-SIX CHILDREN ATTENDING NURSERY SCHOOL, 1939-1942

\begin{tabular}{|c|c|c|c|c|c|c|c|c|c|}
\hline \multirow{2}{*}{ Initial } & \multirow{2}{*}{\multicolumn{2}{|c|}{ Problems }} & & \multicolumn{6}{|c|}{ Children } \\
\hline & & & Total & Group & $I$ & Group & $I I$ & Group & II] \\
\hline & To & al. & 26 & 12 & & 7 & & 7 & \\
\hline $\begin{array}{r}1=4 \\
5=9 \\
10=1 \\
15=0\end{array}$ & $\begin{array}{l}\dot{0} \\
\dot{4} \dot{0} \\
\text { ver. }\end{array}$ & 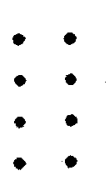 & $\begin{array}{r}7 \\
14 \\
3 \\
2\end{array}$ & $\begin{array}{l}6 \\
3 \\
3 \\
0\end{array}$ & & $\begin{array}{l}0 \\
5 \\
0 \\
2\end{array}$ & & $\begin{array}{l}1 \\
6 \\
0 \\
0\end{array}$ & \\
\hline Problems: & $\operatorname{Imp}$ & ved & Total & Group & $I$ & Group & II & Group & III \\
\hline & To & al. & 26 & 12 & & 7 & & 7 & \\
\hline $\begin{array}{r}1-4 \\
5-9 \\
10-1\end{array}$ & $\begin{array}{l}\dot{\bullet} \\
\dot{4} .\end{array}$ & 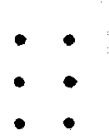 & $\begin{array}{r}13 \\
10 \\
3\end{array}$ & $\begin{array}{l}5 \\
5 \\
2\end{array}$ & & $\begin{array}{l}4 \\
2 \\
1\end{array}$ & & $\begin{array}{l}4 \\
3 \\
0\end{array}$ & \\
\hline
\end{tabular}

The twelve children of Group I were considered by the nursery school staff to have either (I) presented few problems upon entrance to Nursery school and continued to show a good adjustment, or (2) showed a great amount of improvement in their problems presented upon entrance.

There were five children in Group I who showed very few problems when referred to Nursery School. The case of Mary, 4, is presented as an illustration of these five: 
Mary's father was a factory foreman and seemed to have no difficulty in supporting the family of four. Mary was an average child with an IQ of 114 as tested before entering Nursery School. She was a sweet-mannered child who adjusted easily at school. Her only difficulty was in telling her mother good-by at first, but she soon did this easily. She was well-liked at Nursery School and had a very good time. The psychologist reported she seemed very well adjusted socially in that she was friendly, outgoing, and cooperative.

The remaining seven children in Group I showed problems when entered in Nursery School, yet were felt by the staff to have shown a great deal of improvement in their adjustment to Nursery School. The major problems disappeared or were improved to such a degree that it was felt the child would have little difficulty in adjusting to elementary schools. The following case history illustrates such an adjus tment:

Hartha, a three-year old child, presented a picture of an al most miraculous change as a result of her nursery school experience. Her mother was mildy depressed with suicidal tendencles. She was married to a man much older than herself, who had a sixteen-year old daughter from a previous marriage. The mother feit burdened down with the drab existence and low economic level of her husband's grocery store. The parents were extremely over-protective of Martha, and had almost "wrapped her in cotton for safe-keeplng", waiting on her hand and foot.

When she was brought to the Nursery School, she had poor eating habits, was over-dependent on her mother, shy, lacked spontaneity and conHidence; and had temper tant rums, cried frequently, refused to go to bed, was fearful of high places, spoiled, presented problems of nail biting, mild stuttering, masturbation, and day dreaming. 
Her mother was helped by the psychiatrist to gain confidence in herself and to express her feelings. Her anxiety left and she was able to be more independent and take more initiative. She improved greatly in handing Martha's problems. In play therapy with the social worker, liartha let out a great deal of negative feeling and aggression and obtained relief. By the end of her treatment, she was a different child. She was no longer timid, fearful, and retiring. Instead, she was selfconfident, vivacious, and outgoing.

In Nursery School, Martha's general condit ion showed a wanderful improvement. Instead of sitting and watching, she began to take part happliy in all activities. She was no longer a problem with eating am sleeping habits. As soon as she overcame her timidity, her progress was rapid. She became very independent and refused to let her parents do everything for her. She was able to assume leadership of the eroup. She became unafraid of new people and places. She always seemed to enjoy Nursery School and reached the polnt where she could participate, use her own ideas, and resourcefulness and imagination with a great deal of freedom. The staff was fascinated by her growth and blossoming-out into a delightful youngster.

Group II was group of seven children who showed little or no improvement from the ir nursery school experience. It. was felt by the nursery school staff that very little had been accomplished with this group of children. In six out of seven cases in this group, the parent could not accept help from clinic treatment with her own emotional problems or with her problems with the child. The child was eit her removed from Nursery school entirelly before any improvement resulted from school attendance, or the parent's problems remained unchanged and continued to 
affect the child's behavior at home or school or both. The following case illustration is of a child in Group II who had little difficulty in adjusting to Nursery school and made rapid improvement in her problems at school, but continued to be a problem at home due to the parent's inability to benefit from clinic treatment:

Sylvia, three, was an only child of parents who had spoiled her completely. They became irritated at her difficult behavior, yet were "crazy about her". The problems shown by Sylvia were: severe temper tantrums, enuresis, eating problem, thumb suckine, willful and negative behavior, crying for attention, whining, restlessness during sleep, hitting an annoying other children and adults.

After a week in Nursery School, Sylvia cam into the group wi thout crying and had few temper tantrums. When she learned that her undesirable behavior did not get her what she wanted at nursery school, she became one of the most helpful and cooperative children there. Adults and children both liked her and her teacher reported that she was a lovely child to have in the group. At school she became a real power for the good and showed a great deal of self-reliance and thoughtful initiative.

It was doubtful whether the mother received any help from her clinic visits. She continued to be inc on sistent in her handling of Sylvia, giving into her every whim rather than bring on another temper tantrum. Sylvia's babyish actions continued at home, because her parents let them work. When away from home, she became a very well-adjusted child, but she was still a serious problem in the home.

This next case illustration is of one of the children in Group II who was removed from Nursery school entirely because the parent was unable to accept help wi th her own emotional problems: 
Douglas, $6 \frac{1}{2}$, was brought to Nursery school as he was unable to adjust to kindergarten in public school. His mother reported that he spent most of his time outside of the room because the teacher was unable to deal with his misbehavi or in the classroom. He showed generally undesirable aggressive behavior- showing off for attention, hyper-activity, was imrature socially, unable to get along with his siblings, was disobedient, and blocked completely against formal schooling.

From the first, he showed a tendency to annoy other children at Nursery school and was amazed when his misbehavfor was ignored by the teacher. His only activity was in climbine and jumping of things. Through games and stories, he began to learn to spell and write. He could add and subtract simple sums and learned to enjoy singing with the group. He began to show a little more feeling for the other children, and showed less need for being engaged constantly in some physical activity. His span of attention lengthened and he began to show more interest in his work.

Just when Douglas was showing some improvement in Nursery School, his mother removed him, saying that she found it impossible to continue him in school. It was felt by the staff that her domination was a stumbling block to Douglas and it was too difficult for her to change her emotions so that he could express himself more freely.

Two of the children from Group II came from such a poor home situation that it was felt that the eircumstances at home would counteract any permanent good accomplished in the irregular and short term of attendance of the children in Nursery School. The $f$ ather was unemployed, the family of six lived in one room, there was a great deal of illness in the home, and the children suffered from a lack of proper nourishment and care. 
The seventh child in Group II was in very poor health during her month's attendance at Nursery School and, for this reason, there was not much change in her behavior.

Group III is composed of seven children whose improvement at Nursery School was doubtful. This made it difficult to classify them in either Group I or Group II. As they seemed to belong to neither group, they were left in a classification by themselves to form a third group. This unclassified group may be considered with Group II as a group of dabtful improvement consisting of fourteen members. When this is done, there is a better basis for comparison with Group I of twelve children showing improvement. Frequent absences retarded improvement for two of the children in Group III. The following is an illustration of doubtful improvement due to absences:

The problems presented by Peter, 4, at the time of referral were temper tantrums, a speech defect, a tendency to stutter. He was "affecthungry", shy, and insecure. He had an eventempered disposition, was extremely kind and generous with other children. He was very quiet and appealing and seemed to be self-conscious about his speech defect. In six interviews with the psychiatrist, Feter was able to get out a good bit of aggression, although it was felt that the mother got Iittle help from her contact with the clinic.

Peter improved in initiative and aggression, became more outgoing, cooperated well; yet always preferred to be directed by another child. His indistinct speech and hesitancy to talk did not improve. What improvement he appeared to be making was retarded by his frequent absences from Nursery school of a week or more at a time, and he had to regain self-confidence all over again. 
Marshall is given to illustrate the two children in Group III whose improvement was doubtful, due to the counter-action of a very unstable home situation:

Marshall, $4 \frac{1}{2}$, had temper tantrums, showed sibling rivalry, was unable to get alone with other children, seemed to confuse fact and fantasy, was highly distractible, and hyperactive. He was handicapped by a mal development of his cere rum and al so by an internal strabismus of his left eye. Due to a lack of motor coordination, he appeared to be clumsy, and would fall in walking. His I on two psychological tests was 89 , or a dull normal.

His father had an ungovernable temper, and had difficulty in managing on present earnings, due to illnesses and accumulation of debts. He was abusive to his wife and liarshall. His mother was a religious fanactic, believing in no social activity. There was al ways a conflict of interests between the two parents due to the mother's condemnation of her husband's drinking and dancing. Marshall spoke of his parents as being "mixed up". His older sister and younger brother were favored by the two parents, causing Marshall to feel neglected and to show a great deal of need for belonging to something.

Marshall did not present at Nursery School any of the problems shown at home, and aside from his confusion of fact and fantasy, he was quite satisfactory to have in the school. He learned to control his temper and not to fly to pieces when upset. He was able to work longer at one thing without shifting. He gained a good social rapport and a real feeling for other members of the group. It was felt that he made as good an adjustment as possible considering the ill effects of the home situation.

After an emotional crisis at home, his behavior altered accordingly. Even when he was excited and upset from home, he was able to get along amiably with the group, showing that his social adjus tment seemed weli enough established not to be seriously disturbed by emotional upheavals, although his own individual performance was affected. His ability to coneentrate on his work varied with the emotional upsets at home. 
The three remaining members of Group III were classified as showing doubtful improvement, because one or more of their initial problems remained unchanged, or improvement was shown inconsistently, as in the case of the boy who had "bad days", or another boy who adjusted very well in his first month of Nursery School, but suddenly became a tyrant, showing very disagreeable behavior in the group in the second month of school.

The third child in this category was difficult to classify as his problems were derived from a spastic birth injury, and there was some question of his remaining problems being due to an organic or an emotional disorder.

Data From Elementary School in 1946

Twenty-two of the 26 children located through the census files of the two Boards of Education, were enrolled in public schools. Three of the se were in county schools; the remaining nineteen were in city schools. Four of the children were enrolled in Catholic parochial schools. Since the study was being made on the basis of the child's adjustment in school as of May-June, 1946 as compared w1th his adjustment in the Nursery School, 1939-1942, no contact was made with the home during the present study. All information obtained about each child at the time of the follow-up study was through (1) interview with the teacher, and (2) school records. 
The teachers were seen in the months of liay and June, 1946. It was felt that they would know the children better at the ond the term. Since the teachers were seen during the last month of the school year, there was the disadvantage due to the pressure of filling out records and grades. However, the fact that they were at the point of evaluation of the child's performance for the year seemed to aid them in their participation in this study.

Three children who had not been located in June, 1946 were found in a re-check of the census files in October, 1946; and their teachers were seen at that time. The teachers for the preceding year were seen in the cases of two children of these children. However, one new teacher was seen as the child's former teacher was not available. The interviews with the teachers were held before the information from the nursery school records was obtained. This was done ( 1 ) as the spring was decided on as the best time to interview the teachers, it was necessary to fill out the schedules from the nursery school records at a later date, and (2) in order to help the author avold bias in the interpretation of the material.

Classification of Children by Interviews with Elementary School Teachers

The problems as reported by elementary school teachers were totalled for each child as a basis for evaluating whether or not the child was considered a problem in 
elementary school. This is shown in Table 3. This method shows which chlldren presented more of the problems included on the schedule. I In a few cases, the teacher mentioned aditional problems. We inferred that the children showing more problems on this list are considered by their teachers to be makine a poorer adjustment in elementary school than those children who present less problems on the list. The types of problems shown by the children in elementary school are seen in Table 20, infra, page $5 \%$.

The list of problems used in this study was derived from Wickman's study of the reactions of teachers to behavior problems. His list of fifty problems was secured "(I) from a questionnaire to the teachers of an elementary public school in which they were asked to en umerate all behavior problems that they had encountered in their teaching experience; and (2) from a compiled list of problems as referred to a Child Guidance Clinic in the same comunity." 2

\section{TABLE 3}

NUNBER OF PROBLENS OE TWENTY-SIX CHILDREN IN ELEMENTARY SCHOOLS, MAY-JUNE, 1946

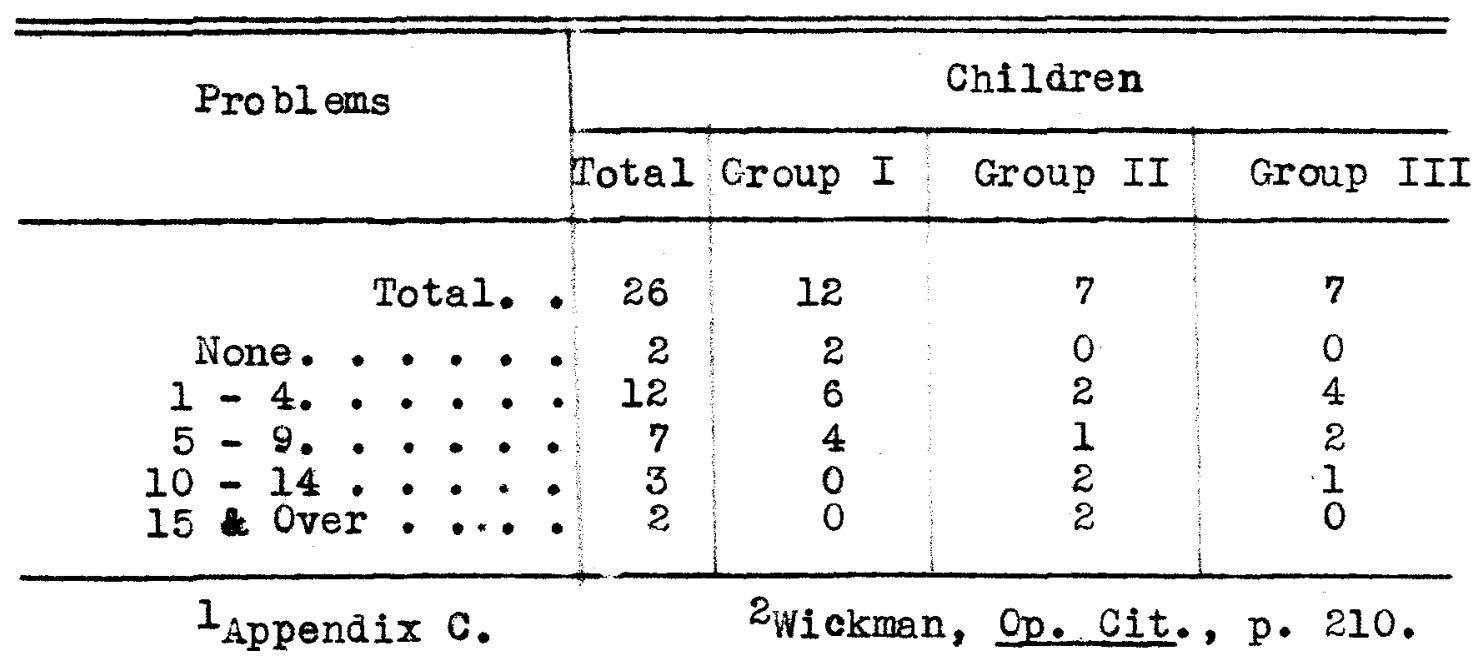


The twelve children showing five or more problems are used in this study as being problem children in elementary schools. The reason for this division is that the teacher's general discussion of children showing five or more problems presents a picture of a child who is not welladjusted to his school situation.

As an illustration, the following is the story of the one child who showed five problems:

He is restless in class with a great deal of nervous activity - moving $h$ is peet and arms in a shuffling motion and biting his nils. He cries easily, turns white when corrected by his teacher, seems shy and withdrawn, shys away from the usual fights with boys his ace, and is backward about answering in class or giving oral performances. He and his twin brother are never apart and seem to have no other close friends. The twin brother has less outstanding qualities than the first twin. He is not as forward and not as good a student. He asks often to be excused from the room, and his health record states that he wets the bed at home. He is sulky and sullen, whereas the first twin is not considered to be so.

The following is an illustration of a boy, who presents the Ereatest number of problems, (20), of the group studied in elementary school:

Charles is considered to be an extreme discipline problem in his classroom. He is inattentive, does not study, is careless in his work, indifferent and sluggish. He inter rupts the classroom, attracts the attention of others in the room with his misbehavior, is quarrelsome, stubborn, defiant, and challenges the teacher and principal when it becomes necessary to discipline him. He is selfish, very restless and unable to concentrate. He has frequent temper outbursts. He is, however, on the other hand, considered by his teacher to be a big bluff and bully. 
He daydreams, seems oversensitive, is sulky, and seems to be cowardly. His teacher refers to him as a "show-off coward". He bullies the younger and smaller children. The other chilaren say, "We should send him to another school--we don't want him here."

This is a picture of one of the children whom the teacher considered to be no problem in the classroom:

Her teacher reports that Marjorie is a "lovely child" who does outstanding work. She takes the initiative very often in the room, is popular with the others, and makes a go od leader. She expresses herself well both orally and verbally, and has had several stories published in the school magazine. She is quiet, well-behaved, adapts herself well to the group. She is an "all-round sweet little girl".

It is at this point that we encounter a serious difficulty - in considering whether or not the children are problems in el ementary school and nursery school, and to what degree they are problems. What is acceptable behavior to one parent, teacher, or school sys tem may become unacceptable when the child pesses into the control of another parent, teacher, or school.

The difference in attitude of mental hygienists and public school educators has been referred to in several studies. "In making the comparison between the attitudes of mental hygienists and teachers, it is essential to bear in mind the differences in professional interest. The focus of attention and interest for the mental hygienist is the social and emotional adjustment of the child; the chief interest of the teacher is in the educational accomplishments 
of chilaren."l This difference in the principal interests of the two professions naturally brings about different attitudes toward child behavior.

In view of the scholastic function of public school edutation, a "great emphasis has been placed on grades, units, and degrees; and compulsion in subject matter regardless of health, interest, ability and achievement." 2 There is not sufficient time for the teacher to give adequate attention to the individual needs of her children.

"In contrast to the public school, the nursery school appreciates the need of individual attention to the child and offers opportunity for it. It permits only small numbers of children per teacher, has no curriculum as such, and places the personality problems of the individual above the program in Importance. The nursery school appreciates the need for training the whole child and for understanding and, to some extent, modifying the influences that bear upon the child outsiae the school." 3

Table 4 shows that fire of seven of the unimproved group at Nursery School remain problems in elementary school. Three of seven showing doubtful improvement are still considered to be problems. Eight, or two-thirds of the children considered to be problems in schools in 1946 came from the two groups where it seemed doubtful that they had improved at Nursery School. 


\section{TABLE 4}

ADJUSTMENT OF TWENTY-SIX CHILDREN IN DLENIENTARY SCHOOLS, 1946, ACCORDING TO DEGREE OF IMPROVELENT IN NURSERY SCHOOL, 1939-1942

\begin{tabular}{|c|c|c|c|c|}
\hline \multirow{2}{*}{$\begin{array}{c}\text { Evaluation of } \\
\text { School Adjustment }\end{array}$} & \multicolumn{4}{|c|}{ Children } \\
\hline & $T$ & Group I & Group II & Group III \\
\hline Total. . & 26 & 12 & 7 & 7 \\
\hline $\begin{array}{l}\text { Considered to be a Problem } \\
\text { Considered to be no Prolem }\end{array}$ & 12 & $\begin{array}{l}4 \\
8\end{array}$ & $\begin{array}{l}5 \\
2\end{array}$ & $\begin{array}{l}3 \\
4\end{array}$ \\
\hline
\end{tabular}

In view of the unreliabilities that we have discussed of this method of study, a later study might reveal more objective data through: (1) contact with the home, (2) use. of a control group of chilaren who did not at tend nursery school, or (3) the method of asking the teachers to rate the nursery school child with all the children in the room for comparative purposes, rather than to single out the nursery school child for an evaluation of behavior as was done in this study. 
CHAPTER III

HOME SITUATIONS OF THE CHILDREN 
CHAPTER III

HONE SITUATIONS OF THE CHILDREN

This section of the study is devoted to the influence of the home as shown by the child's behavior at Nursery School and in elementary school.

\section{Sociel Service Exchange Registration}

Social Service Exchange registrations were checked in Ootober, 1946. Table 5 shows the agencies registered and the frequency with wich the registrations appeared. Separate classifications of public health agencies and social agencies were made because some of the families were known to one type of agency and not to the other. Twelve families had had no contact with public health agencies, eight were unknown to any social agency, and seven were unknown to either type of agency.

There does not appear to be any real basis for stating that more children with problems come from families with frequent social agency registrations, or that the reverse is true. However, of the children who came from families with registrations with more than one public health agency, seven were in Groups II and III, and four were in Group I. of the 
families registered with more than two social agencies, seven were in Groups II and III, and two were in Croup I.

Two children whose families had the most frequent social agency clearings, fifteen, (including both health and welfare agenciesl, were found to be problems in elementary schools. The child having the next most frequent number of clearings with Social Service Exchange, eleven, was also considered to be a problem in elementary school. The chilaren from the families with the next most frequent social and health agency registrations, (ten, nine, seven, and six), were not considered to be problems in public schools. Four of the seven children whose families were known to neither social agencies nor health agencies, were considered to be problems by their el ementary teachers.

TABLE 5

SOCIAL SERVICE EXCHANGE RECISTRATION ON IHE FAIILIUS OF TWENTY-SIX CHIDREN IN ELUWENTARY SCHOOLS, 1246

Social Agencies

Agency Registrations Agency Registrations

Mental Fyglene Clinic. $15^{2}$ Louisville Goodwill Industries 3 Family Servioe Organization8 Home of the Innocents. ? 7 Lunicipal Bureau of. * " Social Service . . 6 Legal Aid Society. • 5 Louisville \& Jefferson Co. Children's Eome. • 5 Juvenile Court .... 4 Chlldren's Agency. . . 4 American Red Cross.... 3 Aid to Dependent Children \& Afd to Dependent Families. 3 Neighborhood House Day Care Center * • • • • 2 City Workhouse . . .... 1 City Housine Law Division. - I Federal Correctional Institute, Ashland, Ky.... I clinfe policy was to fegister the family with Mental Hyiene only if the family had previous registrations. 
TABLE 5 (CONTINUED)

Public Health Agencies

\begin{tabular}{|c|c|c|}
\hline Agency & Registrations & Registrations \\
\hline $\begin{array}{l}\text { Visiting Nurse } \\
\text { Children's Free } \\
\text { Loulsville \& Je } \\
\text { Health Departm }\end{array}$ & $\begin{array}{l}\text { As sociation } 11 \\
\text { Hospital. } 6 \\
\text { efferson Co. } \\
\text { nent. } \cdot \cdot 5\end{array}$ & $\begin{array}{l}\text { Louisville General Hospital- } \\
\text { Department of Psychiatry. } 3 \\
\text { Loui sville General Hospital- } \\
\text { Social Service Department .3 }\end{array}$ \\
\hline
\end{tabular}

\section{Marital Status of Parents}

Table 6 is concerned with the parent's marital status. The findings here are significant only as the study in 1946 brings out that all, with one exception, of the children who came from broken hames, are considered to be problems by their teachers at the time of the follow-up. All of the parents who were divorced or widowed when the children were in Nursery school have married again. The child whose father was separated from his family is in the home of a maternal aunt because his mother died two years ago, and the father refused to take the responsibility for his children.

The one exception, who is not considered a problem in elementary schools, was living with his mother and stepfather whlle in Nursery School and the mother and stepfather were able to receive some help from their clinic contact in the parent-ohild relationship, so that the child was considered no problem when he left Nursery School. 
TABLE 6

MARITAL STATUS OF PARENTS OF TWENTY-SIX CHILDREN ATTENDING NURSERY SCHOOL, 1939 - 1942

\begin{tabular}{|c|c|c|c|c|c|}
\hline \multirow{2}{*}{ Marital } & \multirow{2}{*}{ Status } & \multicolumn{4}{|c|}{ Children } \\
\hline & & Total & Group I & Group II & Group III \\
\hline & Total. & - 26 & 12 & 7 & 7 \\
\hline $\begin{array}{l}\text { Married } \\
\text { Divorced } \\
\text { Separate } \\
\text { widowed }\end{array}$ & 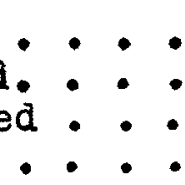 & $\begin{array}{r}20 \\
\text { - } \quad 1 \\
\text { - } \quad 1 \\
4\end{array}$ & $\begin{array}{l}9 \\
1 \\
0 \\
2\end{array}$ & $\begin{array}{l}6 \\
0 \\
0 \\
1\end{array}$ & $\begin{array}{l}5 \\
0 \\
1 \\
1\end{array}$ \\
\hline
\end{tabular}

\section{Socio Economic Level of Parents}

The children were distributed fairly evenly accordIng to socio-economic level of their families. Table $\eta$ shows that four of Group I came from families with a comfortable standard of living, four came from families of average means, and four came from families of a low economic level. No children of this group came from families dependent on relief. Of Groups II and III, six were from comfortable families, two from average families, two from poor families and four from families dependent on relief.

The classification of comfortable standard of living includes both professional and clerical occupations. The four professional fathers included one dentist, one doctor, and two lawyers. The clerical profession consisted of an insurance auditor, owner of a wholesale establishment, manager of an automotive store, a salesman, and a grocery store owner . 
In the average standard of living group, there was a grocery owner, a WPA clerical worker, and a clerk in a factory stock room. The skilled laborers included a factory foreman, boiler-room engineer, and a fireman.

The low economic level group included unskilled laborers, janitors, and tmose doing other manual labor jobs. Three of the four families on relief were receiving financial aid from Family Service Organization. One mother was receiving a grant from Aid to Dependent Children.

\section{TABLE 7}

SOCIO-ECONOMIC LEVII OF THE PARENTS OF TWENTYSIX CHIIDREIT AINENDING NURS ERY SCHOOL, 1939 1942

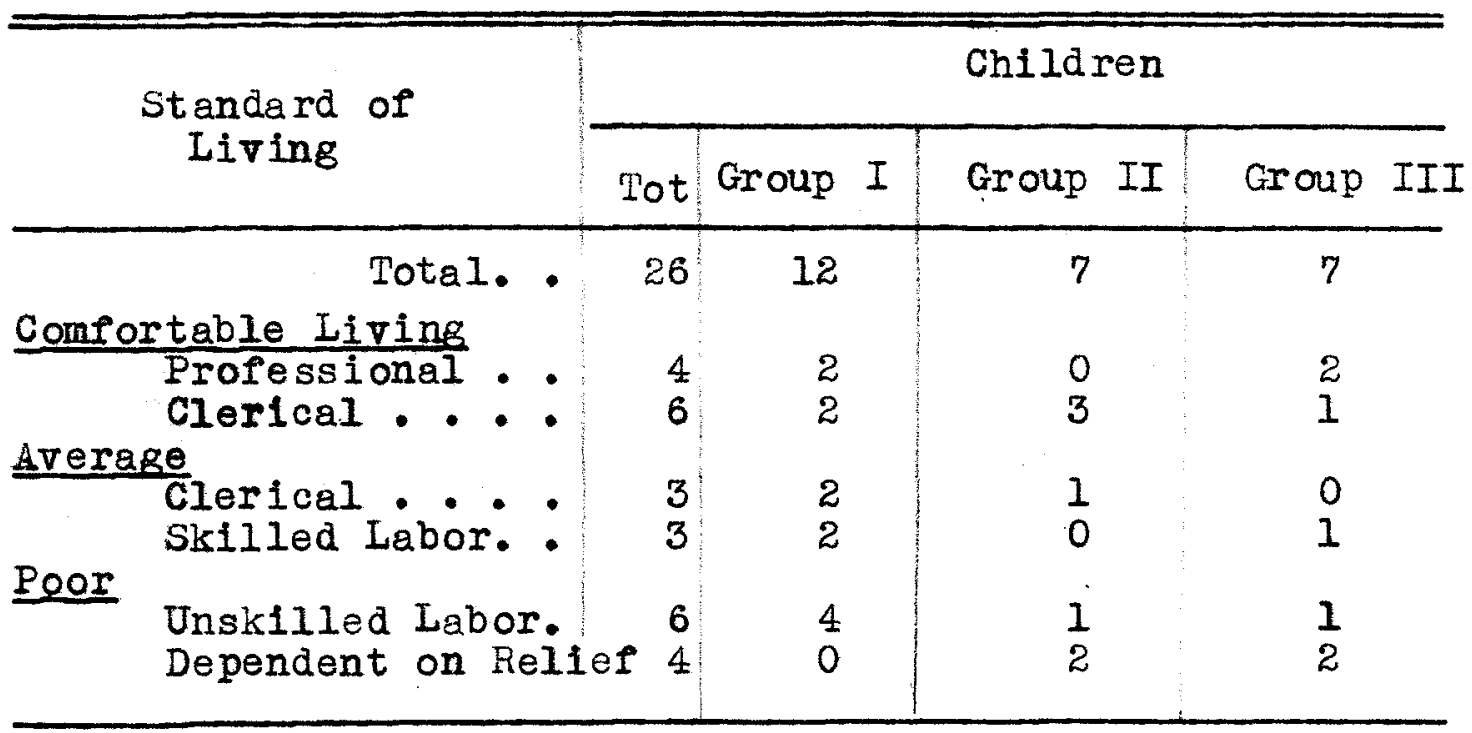

Of the ten chlldren from comfortable homes, three of them are considered to be problems in elementary school. One of the six children of average home is considered a problem, and eight of the ten children of poor and dependent homes are considered problems at the time of the follow-up 
study. The basis for the socio-economic level in elementary school was the same as that of Table 7, or as the homes were at the time of the child's attendance in Nursery school, so we can question the validity of this data in consideration of the changing economic conditions from 1939 - 1946.

A similar study of the relation between socio-economic level and children's behavior was done at the Washington Child Guidance Clinic. A group of fifty children from homes of high economic level who had been referred to the clinic were studied with a control group of fifty children from dependent homes from the same source. ${ }^{1}$ The types of problems presented by these one hundred children were grouped as: (1) habit problems, (2) aggressive personality problems, (3) submissive personality, and (4) educational difficulties. Since the problems in our study of twenty-six children were classified similarly in Table 21, we can compare our results with the washington study.

TABIE 8

SOCIO-ECONORIC LEVEL OF TWENTY-SIX CHILDREN BY TYPES OF PROBLEMS

\begin{tabular}{|c|c|c|c|c|c|}
\hline \multirow{2}{*}{ Socio-Economic Level } & \multicolumn{5}{|c|}{ Types of Problems } \\
\hline & Tot & Aggressive & Withdrawing & Classioom & Habit \\
\hline Total. & 153 & 68 & 44 & 31 & 10 \\
\hline $\begin{array}{l}\text { Comfortable. } \\
\text { Average. } \\
\text { Poor and Depondent }\end{array}$ & $\begin{array}{l}49 \\
21 \\
83\end{array}$ & $\begin{array}{r}25 \\
7 \\
36\end{array}$ & $\begin{array}{r}8 \\
7 \\
29\end{array}$ & $\begin{array}{r}11 \\
6 \\
14\end{array}$ & $\begin{array}{l}5 \\
1 \\
4\end{array}$ \\
\hline
\end{tabular}


The findings of this study agree with those of the Washington study in that the high and low socio-economic groups were much alike in the distribution of occurrence of faulty habits. In that study, the dependent group showed twice as many aggressive problems than the comfortable group showed.

Our study differs from the Washington study with regard to the number of submissive traits and number of educational difficulties. Their study found a Ereater number of submissive traits in children from comfortable than in dependent children. Children from the more comfortable homes showed more school maladjustments. This difference might be due to the fact that more problem children in our study were found in the poor and dependent group; thus this group, even though it has the same number of children as the comfortable group, presents eighty-three total problems as against the comfortable group's forty-nine total problems. It is not known whether this was true of the washington study.

\section{Other Features in the Home Situation}

Other features in the home situation that appear to be worth mentioning inasmuch as they affect the child's qdjustment in Nursery School were not recorded consistently throughout. They were recorded only as they were brought out by the mother in her clinic interviews. 
In Group I there was record made of only one case of marital difficulties, whereas in Groups II and III, marital difficulties were brought out in four cases. Occurrences of unstable parents were recorded two times for Group I and six times for Groups II and III. Both marital difficulties and unstable parents affected Mickey's behavior in Nursery School:

Mickey's father has an ungovernable temper; he drinks heavily; gambles; and is abusive to Mickey, the two other children and his wife. Mickey imitates his father's infantile behavior of showing irritation without inhibition. He was the middle child. His older brother was his father's favorite; his younger brother was his mother's favorite. Mickey's sense of deprivation and rejection by his parents was great. Mr. N, Mickey's father, had difficulty managing on his earnings due to his and his wife's constant illnesses and a consequent accumulation of debt. Nis. N. displayed religious $f$ anaticism and $\mathrm{Mr}$. N.'s behavior was in rebellion against this.

Nirs. N. reacted to the conflict in the home by spending most of the time in bed, complaining of being nervous and in poor health. The children's reaction to the strain and tension in the home was to vie for their parent's attention with misbehavior, to tattle on each other, or carry tales from one parent to the other. At Nursery School, Mickey showed a confusion of fact and fantasy, was highly distractible and hyperactive. He displayed temper tantrums, sibling rivalry, and was unable to get along with other children. His ability to concentrate on his work varied with the emotional upsets at home.

Parents having an education below the eighth grade occurred four times in Group I, six times in Groups II and III. Mention of crowded quarters occurred once for Group I and three times for the other two groups. Instances of 
both parents working occurred twice for Group $I$ and three times for Groups II and III.

This is an illustration of how illness in the home affected the child:

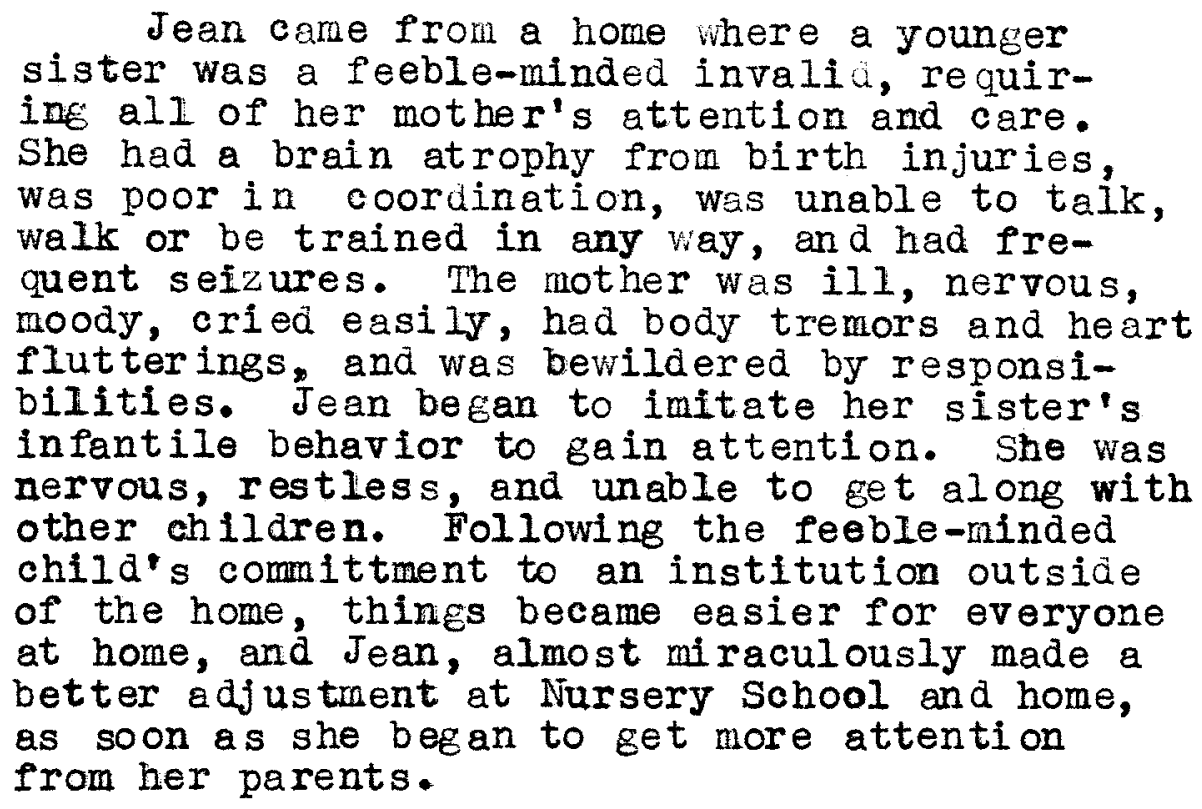

In all of the cases where mention was made of the father having an education below the eighth grade, his occupation was that of a manual laborer, or he was unable to find work at all. It was brought out in Table 7 , supra, page 29, that four-fifths of the children from poor or dependent homes were considered problems in elementary schools, so we see that, indirectiy, limited education of the father has a detrimental effect upon the child's school adjus tment.

A direct effect of crowded quarter was seen in the case of Diana's Nursery School adjustment: 
The family of six was living in one room and the children could get no sle ep until their parents went to bed and the lights were out. Diana was tired, listless, irritable, and showed a lack of proper rest. One day she came to school so tired that she could not play because of lack of sleep the night before.

The effect of both parents working:

Two little firls had to miss Nursery school when the ir family had an economic set-back, and the mother had to help the father in their business. Because of the parent's working hours there was no one to take the children to Nursery school and call for them in the midale of the afternoon. They had to drop out of school before much improvement was seen.

Another effect of both parents working was seen in problems resulting in the parent-child relationship due to the mother's anxiety and guilt reelings about neglecting the child.

\section{Evaluation of Home by Elementary Teacher}

It was found that the teachers of the children in the follow-up in Hay-June, 1946 knew very lit tle about the children's homes as compared with the knowledge that the Nursery school teacher had available of the home conditions. With the present heavy load that teachers are required to carry, they have little opportunity to know much about the life of the child outside the classroom. The policy in the public school is that the visiting teacher contact the home only if the child is a discipline or attendance problem. The visiting teacher and teacher do not al ways have an opportunity to discuss together what information each has regarding the child. 
Five of the teachers knew nothing at all of the child's home. Five others made general statements about the home: "Parents cooperative (or nice)", "Mother seems interested in child's getting school work", or "Seems to be happy home".

An evaluation of the teacher's comments regarding the home situations of the children revealed that six children came from good home situations, or situations where the teacher knew of no unfavorable conaitions for the child's school adjustment. The following illustrates the teacher's evaluations of good home situations:

"Mary's mother is interested in the school, active in the Parent Teacher issociation, and very nice to work with as a parent. She talks with the teacher very often about how Mary is getting alone in school. It seems to be a very happy family."

"Virginia and Rebecca came from a very happy home. The mother shows a great interest in Virginia and her younger sister at school. They are deprived of nothine for their happiness."

Ten of the children, according to the teacher's knowledge of the home situation, came from homes where conditions were known to be having an unfavorable effect upon the child's behavior at school. The following are examples:

"Sally knows she can get what she wants at home, so she antagonizes both parents until she gets it. She has severe temper tantrums, destroys clothing, and throws dishes. When Sally annoys her, her mother cries, becomes nauseated, and gives in to Sally. The father was difficult to get along with and left the home last year." 
"George's parents have marital difficulties and this keeps him upset. The father has lost several jobs because of his ungovernable temper. The mother has convulsions and has spent several months on a ward for mental patients. She says that she feels so helpless and is unable to do much for George."

Table 9 shows that none of the six children coming from good home situations are considered problems by their element ary school teachers. Three of the ten chilaren about whom nothing is known are considered problems by their elementary teachers. Nine of ten children comine from poor home conditions are considered problems in elementary school.

Even though little is known about the homes of the children at the time of the follow-up study, it is evident from what little is known, that where the home is maladjusted, the child reflects this maladjustment in school. TABLE 9

EVALUAIION OF THE HOHE SITUATION OF TWENTY-SIX IIURSERY ECHOOL CHILDREN AT TIME OF THE FOLLOW-UP STUDY ACCORDING TO PHEIR EI EMENTARY SCHOOL ADJUSTMENT

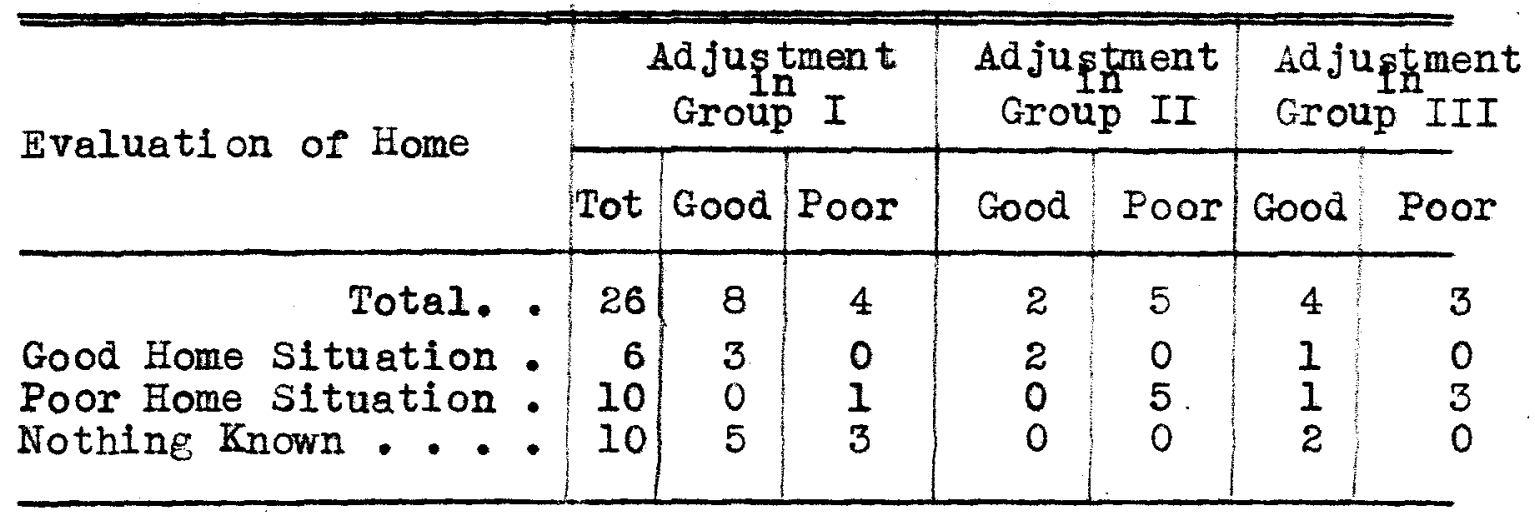


CHAPTER IV

CHARACTERISTICS OF THE CHIIDREN 


\section{CHAPTER IV}

\section{CHARACTERISTICS OF THE CHILDREN}

Age of the Children

As shown in Table 10, the children ranged in age from $2 \frac{1}{3}$ to $6 \frac{1}{2}$ years at the time of their Nursery School attendance. All of the children except two were in the age range of three to five. One boy, 2a, was allowed to come

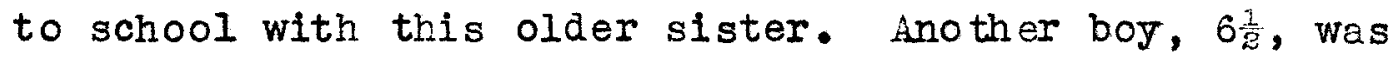
entered in Nursery school because he could not adjust to kindergarten. Both boys are considered serious problems in elementary schools today. Three of the ten children in the age range of three to four during Nursery School at tendance are considered to be problems to their elementary school teachers. Seven of fourteen children aged four to five years at Nursery school are problems in elementary schools.

This finding is not a significant one. However, Ackerson, in Children's Behavior Problems, found in a study of 4,592 child ren aged 0 - 17 years who were examined at a behavior clinic, that the averace number of behavior problems per chlld increased with age up to about twelve years, beyond which there was a decrease. 1

ILuton Ackerson, Children's Behavior Problems, Chicago: The University of Chicaco Pross, 1931), p.256. 
At elementary school, the children's ages ranged from seven to eleven years. An equal number of problem children with a total of seventy-five (75) problems were in the group of twelve children whose ages were below ten, as were In the number of fourteen children showine a total of seventyeight (78) problems who were ten and eleven.

TABLE 10

AGE $A T$ ENLRANCE OF IWETT-SIX CHILDREN ATTENDINC NURSERY SCHOOL, 1939-1942, BY SEX

\begin{tabular}{|c|c|c|c|c|c|c|c|c|c|}
\hline \multirow{2}{*}{\multicolumn{3}{|c|}{ Age }} & \multicolumn{3}{|c|}{$\begin{array}{l}\text { Sex of } \\
\text { Group I }\end{array}$} & \multicolumn{2}{|c|}{$\begin{array}{l}\text { Sex of } \\
\text { Group II }\end{array}$} & \multicolumn{2}{|c|}{$\begin{array}{l}\text { Sex of } \\
\text { Group III }\end{array}$} \\
\hline & & & Tot & Male & Female & Miale & Female & male & Female \\
\hline $\begin{array}{l}\text { Under } 3 \\
3 \text { years } \\
4 \text { years } \\
5 \text { years }\end{array}$ & $\begin{array}{l}\text { Total } \\
\text { years. } \\
\text { under } 4 \text {. } \\
\text { under } 5 \text {. } \\
\text { and ov er }\end{array}$ & 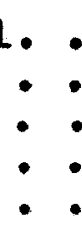 & $\begin{array}{r}26 \\
1 \\
10 \\
14 \\
1\end{array}$ & $\begin{array}{l}5 \\
0 \\
3 \\
2 \\
0\end{array}$ & $\begin{array}{l}7 \\
0 \\
4 \\
3 \\
0\end{array}$ & $\begin{array}{l}2 \\
1 \\
0 \\
0 \\
1\end{array}$ & $\begin{array}{l}5 \\
0 \\
2 \\
3 \\
0\end{array}$ & $\begin{array}{l}6 \\
0 \\
1 \\
5 \\
0\end{array}$ & $\begin{array}{l}1 \\
0 \\
0 \\
1 \\
0\end{array}$ \\
\hline
\end{tabular}

Sex of the Chilaren

By sex, there was an even distribution of males and females in the total group - thirteen males and thirteen females. By droppine the division between the last two groups, there are eight males and six females in the group showing doubtful improvoment; and five males and seven females in the improved group.

Four of eight males are considered problems in the doubtful group; while three of five males in the improved group at Nursery School are considered problems in elementary 
school. Four of six girls in the doubtful sroup at Nursery school continue to be problems in elementary school, while only one of seven girls in the improved Nursery School group is a problem in elementary school. Seven of thirteen boys are problems, and five of thirteen girls are considered problems in schools at the time of the followup study in 1946 .

In Nickman's study of children's behavior and teacher's attitudes, behavior problems were observed by the teachers to occur more frequently in boys than in girls. An average of nearly ten problems was found per boy and six problems per girl. Our study brought out in elementary schools, sixty-six total problems of the thirteen girls, or an average of five problems per girl. The boy's group had a total of elghty-seven problems or almost seven problems per boy.

"The only type of problem in which the girls surpassed the boys (in wickman's study) was in the rating of over-sensitiveness. Shyness was reported with the same frequency for boys and girls. In the manifestation of all the other forms of behavior problems the boys led, usually with a considerable margin." II

In our group of thirteen boys and thirteen girls, the boys presented more problems than girls except in the

$1_{\text {Wickman, }}$ Op. Cit., p.45. 
following cases: girls were reported to be defiant in three cases, boys in one; eirls tattled four times, boys three; girls were shy five times, boys four; girls daydreamed five times, boys three; four Eirls were meticulous, no boys were meticulous; and two girls had nervous tics, no boys presented this problen.

According to wickman, "teachers prefer the less active, more complent behavior of girls to the more asgressive, independent behavior of boys". 1 This may account for the fact that boys are considered to show more problems than girls in the elementary schools.

As shown in Table 11, our study shows that boys presented fifteen more aggressive problems and six more withdrawing problems than girls. The two sexes showed practically the same number of habit and classroom problems.

TABLE 11

SEX OF TWENTY-SIX CHILDEN IN ELEMENTARY SCHOOL BY TIPES OF PROBLEMS

\begin{tabular}{c|r|r|r|r|r}
\hline \multirow{2}{*}{ Sex } & & \multicolumn{3}{|c|}{ Types of Problems } \\
\cline { 2 - 6 } & Total & Aggres sive & Withdrawing & Classroom & Habit \\
\hline Tota1. & 153 & 67 & 44 & 32 & 10 \\
Male. & 87 & 41 & 25 & 15 & 6 \\
\hline
\end{tabular}

There is not a great deal of difference in the problems shown by the two sexes as brought out in this study. This might be due to any number of unknown factors which 
must be borne in mind throughout the study, such as the small number involved in the study, the subjectivity of the evaluation of the children's behavior, etc.

\section{Position in Family Group}

As to number of siblings in the families of the twenty six children, six were only children, eight had one sibling, ten had two siblings, and two came from a family of four children. An analysis of the position of the se chilaren among the ir siblings in Table 12 reveals that ten of the group of twelve showing improvement were only children, or the youngest, and two of the fourteen of doubtful improvement were in the same category.

In elementary school, all four children in Group I who were considered problems were only children or the youngest. Three of four only or youngest children in Groups II and III are considered problems by their elementary school teachers. The two findings are contradictory; however, the elementary school data may not be reliable in consideration of the lack of knowledge of later births in the family.

\section{TABLE 12}

POSITION IN TAMILY GROUP OF TWENTY-SIX CHILDREN ATTENDING NURSZRY SCHOOL, 1939-1942

\begin{tabular}{|c|c|c|c|c|c|}
\hline Position Amone & Siblings & Tot & Oroup I & Group II & Group III \\
\hline $\begin{array}{l}\text { Only Child } \\
\text { oldest child } \\
\text { Middie Child } \\
\text { Second child } \\
\text { Youngest Chil }\end{array}$ & $\begin{array}{l}\text { Total. } \\
: \vdots: \\
\text { (of four): } \\
\text { d. }\end{array}$ & $\begin{array}{r}26 \\
6 \\
6 \\
5 \\
1 \\
-8\end{array}$ & $\begin{array}{r}12 \\
5 \\
1 \\
\frac{1}{1} \\
0 \\
5\end{array}$ & $\begin{array}{l}7 \\
\frac{1}{3} \\
\frac{1}{1} \\
\frac{1}{1}\end{array}$ & $\begin{array}{l}7 \\
0 \\
2 \\
3 \\
0 \\
2\end{array}$ \\
\hline
\end{tabular}


Physical Condition

An attempt is made in Table 13 to present an evaluation of the child's physical condition. The basis for judging the physical condition is purely subjective in both school. situations - it is based on (1) teacher's evaluation, or (2) mother's statement. In addition, elementary school teachers had a health record, giving data from physical examinations. Although, physical examinations were given to each child upon entrance to Nursery School, no recorded physical data was available at the clinic.

The classification of good physical condition includes children where the general development was good and no serlous diseases of physical handicaps exist to affect the child's behavior. Also considered was: Is the child active physically? Are there many absences from school due to colds? How does the child compare in size to other children his age? If conditions of poor nourishment, lack of rest, frequent colds or sore throats, defects of posture were evident, the child was considered in average physical condition. The classification of poor health included children with physical defects or cases of severe conditions of malnutrition, lack of proper physical care seen to affect the child's general development.

None of the children classified as being in good physical condition were considered to be problems in elementary school. There were no children considered in poor health in Group I ei ther in Nursery School or el ementary school. 


\section{TABLE 13}

PHYSICAL CONDITION OF TNENTY-SIX CHILDREN ATTENDING NURSERY SCHOOL ACCORDING TO ADJUSTMENT THERE AND IN ELERIENTARY SCHOOLS, 1946

\begin{tabular}{|c|c|c|c|c|c|c|c|c|}
\hline \multirow{2}{*}{ Physical Condition } & \multirow[t]{2}{*}{ Tot } & \multicolumn{2}{|c|}{ Nursery } & \multirow{2}{*}{$\frac{\text { School }}{\text { III }}$} & \multirow[t]{2}{*}{ Tot } & \multicolumn{2}{|c|}{ Elementary } & \multirow{2}{*}{$\frac{\text { School }}{\text { III }}$} \\
\hline & & $I$ & II & & & $I$ & II & \\
\hline Total. & 2 & 12 & $\overline{7}$ & 7 & 26 & 12 & 7 & 7 \\
\hline $\begin{array}{l}\text { Good. ..: : : } \\
\text { Average }:: \text { : } \\
\text { Poor } \\
\text { Nothing Recorded: }\end{array}$ & $\begin{array}{l}6 \\
9 \\
7 \\
4\end{array}$ & $\begin{array}{l}3 \\
6 \\
0 \\
3\end{array}$ & $\begin{array}{l}0 \\
1 \\
5 \\
1\end{array}$ & $\begin{array}{l}3 \\
2 \\
2 \\
0\end{array}$ & $\begin{array}{r}7 \\
15 \\
4 \\
0\end{array}$ & $\begin{array}{l}6 \\
6 \\
0 \\
0\end{array}$ & $\begin{array}{l}1 \\
4 \\
2 \\
0\end{array}$ & $\begin{array}{l}0 \\
5 \\
2 \\
0\end{array}$ \\
\hline
\end{tabular}

The differences in the ratings of physical condition at Nursery School and elementary school could be due to (1) subjectivity of the teachers' evaluations, or (2) a change in the child's condition.

A comparative study of a nursery-school versus a nonnursery-school group was carried on in the Franklin and Winnetka public school nurseries by the Elizabeth Kic Cormick Memorial Fund and the Pre-School Department of the Illinois Institute for Juvenile Research. Ceneral medical examinations were given by the same pediatrician at the beginning and at the close of the school session to see whether those children attending nursery school were in better physical condition then their control group who did not attend nursery school. "On summarizing the medical examinations, the nur sery school group seems to be in slightly better 
condition than the control group, but the differences are too small to be significant."

A study made by Paynter and Blanchard of the Educational Achievement of Eroblem Children reaches the conclusion from studying physical condition that "apparently, our children with personality and behavior difficulties show no undue number of physical defects." 2

From a comparison of these studies of physical conditions of children, it seems that we can reach no conclusion whether or not children presenting more behavior problems than others have a less desirable physical condition.

\section{IQ of the Children}

Table 14 shows the distribution of children in nursery and elementary schools by IQ. The scores used here are those made on the first psychological tests at Nursery School. The revised Stanford-Binet Intelligence, Forms $L$ and $M$ were used. No significant findings are revealed in an analysis of the second test scores. Six children made a lower score on the second test, two made the same score, eight improved in score from $1-10$, and six improved from 10 - 20 points in Id. "The considerable

$$
1_{\text {Kawin, Op. Cit., p.3l. }}
$$

2Richard Paynter and Phyllis Blanchard, A Study of Educational Achi evement of Problem Children, TNew York: The Commonwealth Fund, 1929, p.29. 
rise in I in so many instances does not mean that the children's intelligence was increased, but would seem to indicate that when a child's emotional problems are worked out or lessened, he is better able to use the innate potentialities he has."I

IQ tests are given in el ementary schools only in cases where a serious maladjustment of the chila indicates a need for one. The Otis General Intelligence Test is given to all children in the sixth grade; however, $5-\mathrm{A}$ was the highest grade achieved by any of our twenty-six children. Therefore, there is no basis for comparison of Iq scores with elementary school tests.

TABLE 14

IQ'S OF TWENTY-SIX CIIILDREN IN IURSERY SCHOOL, $1939-1942$

\begin{tabular}{|c|c|c|c|c|c|}
\hline & $I_{Q}$ & Total & Group I & Group II & Group III \\
\hline & Total. & 26 & 12 & 7 & 7 \\
\hline $\begin{array}{r}80 \\
90 \\
100 \\
110 \\
120 \\
130\end{array}$ & 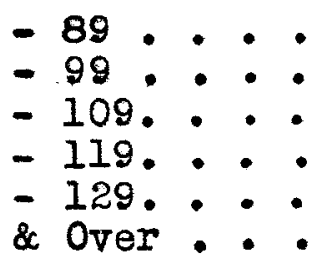 & $\begin{array}{l}2 \\
6 \\
5 \\
4 \\
7 \\
2\end{array}$ & $\begin{array}{l}0 \\
3 \\
2 \\
2 \\
4 \\
1\end{array}$ & $\begin{array}{l}0 \\
2 \\
2 \\
1 \\
2 \\
0\end{array}$ & $\begin{array}{l}2 \\
1 \\
1 \\
1 \\
1 \\
1\end{array}$ \\
\hline
\end{tabular}

In Groups I and II, the children showing problems in elementary schools tend to have lower than average or higher than average IQ's. However, the contrary is true

IMildared Merrifield, "Second Year study of Mental Hygiene Clinic Nur sery School Children", Louisville, Ky., June, 1942. (Unpublished Report) 
in Group III - those showine Iower than average and one showing higher than average IQ's are not problems in elementary school. Five of the children considered to be problems came from the group with IQ's below 100; three problem children came from the group with IQ's 100- 119 and four came from the group with IQ's 120 and over. An analysis of the types of problems is shown in Table 15. Eight children are in the group with IQ's below 100, nine have an IQ $100-119$, and nine have an IQ of 120 and over.

\section{TABLE 15}

IQ OF TWENIY-SIX CHIIDREN IN ELEMANTAFY SCHOOL BY TYPES OF PROBLEMS

\begin{tabular}{|c|c|c|c|c|c|}
\hline \multirow{2}{*}{$I Q$} & \multirow[b]{2}{*}{ Tot } & \multirow[b]{2}{*}{ Aggressive } & \multicolumn{3}{|c|}{ Problems } \\
\hline & & & Withdrawing & 01 assfoom & pabit \\
\hline $\begin{array}{l}\text { Total. } \\
\text { Below } 100 . \\
100-119 . \\
120 \& \text { Over. }\end{array}$ &. $\mid \begin{array}{r}153 \\
49 \\
55 \\
49\end{array}$ & $\begin{array}{l}67 \\
20 \\
24 \\
20\end{array}$ & $\begin{array}{l}44 \\
18 \\
16 \\
10\end{array}$ & $\begin{array}{r}32 \\
7 \\
11 \\
14\end{array}$ & $\begin{array}{r}10 \\
4 \\
1 \\
5\end{array}$ \\
\hline
\end{tabular}

The average group, 100 - 119, shows more aggressive problems than the other groups. The group with Iq's below 100 shows more problems of a withdrawing nature and those with an $I_{Q}$ of 120 and above show fewer withdrawing problems. More problems that conflict with classroom requirements are shown by the group with an above-average Ia and few problems of this nature are shown by those with a below-average IG. The group with an above-average I shows more habit problems than the other groups. 
In measuring total behavior problems, the belowaverage group presents forty-nine, the above-average group presents forty-nine, and the average group shows the greatest number of problems, fifty-five.

Ethel Kawin's study of a nursery-school versus a nonnursery-school group revealed that "according to the results on the Merrill-Palmer Scale, both groups made an apparent gain in mental growth between the fall and spring psychological tests, but there was no difference between the nursery-school group and the control group in the amount of their respective gains."l

Paynter and Blanchard's study of 167 problem children in Los Angeles revealed that there were more problem children having IQ's from 90 - 109. The next greatest number of problem children occurred in the group with an IQ from $80-89$, and the numbers of children with problems decreased gradually from IQ's of 110 to 130 and over. 2

Ackerson concluded in his study that "among younger children of both sexes aged $5-12.9$ years, behavior problems increased markedly with IQ level up to about 119 Iq, beyond which there was probably some decrease." 3

As was true in the comparison of studies of the physical conditions of children, we find a variance in the results of these several correlations of $I_{Q}$ and behavior problems in chlldren. Several factors contribute to the

1 Kawin, Op.Cit., p.49. 2Paynter \& Blanchard, Op.Cit. ,13. 3 Ackerson, Op.Cit., p.251. 
confusion in this area - the imperfection of psychological tests, the difference in methods used in the various studies, and the probably difference in the tests used to obtain the IQ's. The general trend, however, in an analys is of the studies seems to be for behavior problems to be less frequent in the above-average group of IQ's in children, although the studies do not agree on scores of above-average. The average If group seems to be the maximum level for behavior problems with decreases in both directions.

\section{School Achievement}

According to Table 16, four chlidren were making low grades and were considered problems. One of these had an above-average I 4 , one average, and two below-average. Seven of the seventeen children making average grades were considered problems. Three of these had a high Iq, one average, and three below-average. One of the five children making above-average grades was considered to be a problem with an average IQ.

It is well to bear in mind, however, at this point, that the goal of the elementary school teacher is scholastic achievement, and to her the most serious problem would be the child who failed to meet this requirement and makes low grades. It is to be expected that this fact will play a big part in the teacher's evaluations of problem children. 
TABLE 16

SCHOOL ACHIEVBUINT OF TWFITY-SIX CHILDREN IN ELELENTARY SCHOOL, 1946

\begin{tabular}{r|r|r|r|c}
\hline Grades & Potal & Group I & Group II & Group III \\
\hline Total & 26 & 12 & 7 & 7 \\
Low. $:$ & 4 & 1 & 3 & 0 \\
Average. & 17 & 8 & 3 & 6 \\
High $:$ & 5 & 3 & 1 & 1 \\
\hline
\end{tabular}

In an attempt to learn the grade placement of the children in relation to their age, a scale was use considering $6 \frac{1}{2}$ the average age for beglnning the first grade, seven for $1-A, 7 \frac{1}{2}$ for $2-B$, eight for $2-A$, etc. 1 By the use of this scale, five children were below their grade, three at their grade, and seventeen above their grade.

This classification of erade placement doesnot mean much when it is realized thet only two children considered below their grade were more than a half-grade below. The four other children considered below their grade and seventeen above their grade varied from their grade according to age by only one-half grade which might indicate a difference due to the time of year that the children had birthdays.

Term of Stay in Nursery School

As shown in Table 17, ten of Group I attended Nursery school longer than four months. Three of Group II were in Nursery School for the same period of time. All of Group III attended for four months or longer.

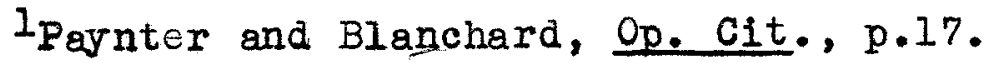


TABLE 17

TERM OF' STAY OF TUEINTY-SIX CHILDREN IN NURSERY SCHOOL, 1939-1942

\begin{tabular}{r|r|r|r|c}
\hline \hline Term of Stay & Tot & Froup I & Group II & Group III \\
\hline Total & 26 & 12 & 7 & 7 \\
One Month. & 1 & 0 & 1 & 0 \\
Two Months & 4 & 2 & 2 & 0 \\
Four Months: & 1 & 0 & 1 & 0 \\
Five Months: & 3 & 2 & 0 & 1 \\
Six Months : & 2 & 1 & 0 & 1 \\
Seven Months: & 3 & 1 & 0 & 2 \\
Etght Months. & 8 & 5 & 2 & 1 \\
Over. - * & 4 & 1 & 1 & 2 \\
\hline
\end{tabular}

One of the two children in Group I attending for two months is considered a problem in elementary schools. Three of the four children in Group II attending for four months or less are considered prablems in school at the time of the follow-up. The one child not considered a problem of these four in Group II attended Nursery School for four months. In summary, two-thirds of the children attendine Nursery school four months or less are problems in el ementary school. Two-fifths of the children attending more than four months are problems in elementary school.

Iittle or no correlation was found between the therapy, or number of interviews at the clinic, with the mother and child and the child's improvement at Nursery School or adjustment at elementary school. Frobably, the major confusing issue in any correlation was that the 
51

control children, or at least the control children showing $f$ ew problems and considered to be adjusted in Nursery School, and their mothers did not have any therapy at the clinic. This would account for the number of children, who, although they had no therapy, were not considered to be problems. Then, also the reverse was true that the children showing the most problems and their mothers were seen at the clinic for more intensive treatment, although they may not have been able to accept a treatment relationship. 
CHAPTER V

BEHAVIOR OF THE CHILDREN 


\section{CHAPTER V}

BEHAVIOR OF THE CHILDREN

Relationship ilth Other Children

It was found that, as in the case of the evaluation of physical condition, the relationship with other children was distributed somewat differently in elementary sehool than in Nursery School. Again, a difference of opinion in the teachers evaluations or a difference in the children's relationships with other children in the two school settings, could account for much of the variance. These two factors should be borne in mind in considering Table 18.

\section{TABLE 18}

RELATIONSHIP WITH OTHER CHILDREN OF TWENTY-SIX CHIIDREN ACCORDING FIO NURSERY SCHOOL ATTENDANCE, 19391942, AND ELEMENTARY SCHOOL, 1946

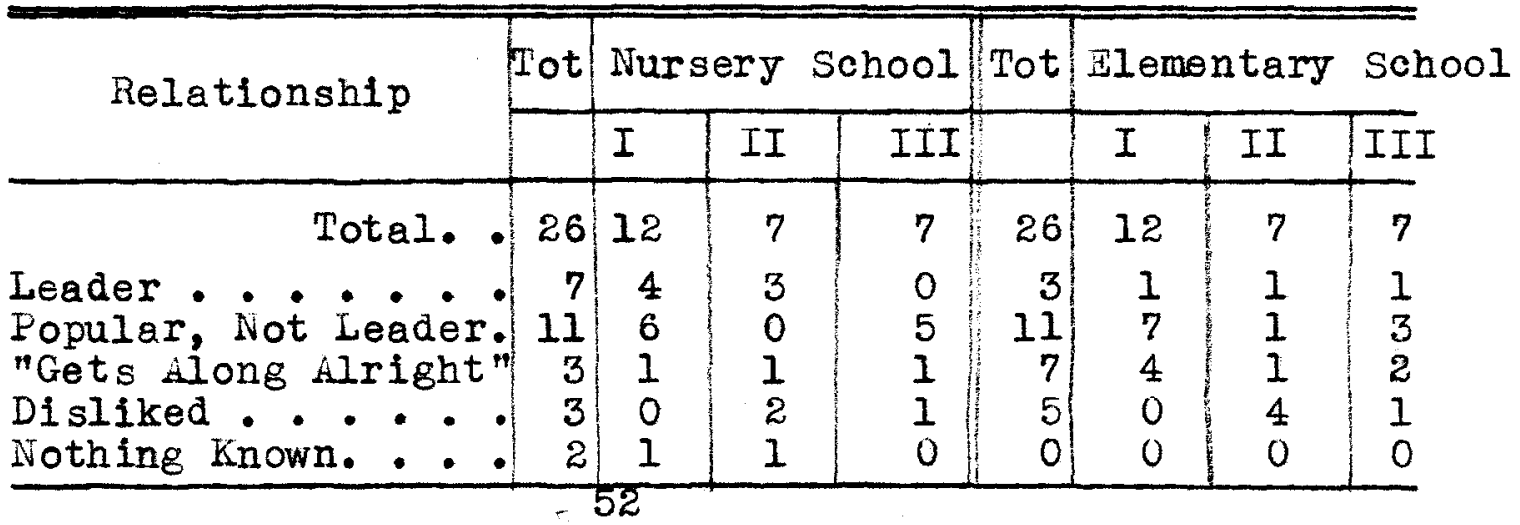


Two of the four children in Group I that were considered to be leaders in Nursery School and the two out of six thought to be popular in Nursery School are considered problem children in elementary schools. In Group II, two of three leaders, one who "got along alright", one of two disliked, and one about whom nothing was recorded are problems in schools at the time of the followup. Two of the five popular children and one considered to get along alright in Group II at Nursery School are problems in 1946.

There is a definite relationship with the elementary school teacher's evaluation of the children being disliked by others and their being problem children. The four disliked in Group II and the one disliked in Group III are considered by their teachers to be problems in the classroom. On the other hand, the three children reported as leaders in elementary schools are not considered to be problems, and nine of the eleven considered popular are not thought to be problems by their teachers. This might show a tendency on the part of the teachers in the followup study to rate children as leaders if they are no problem and to consider them disliken the other children if the teachers themselves think they are a problem. An analysis of the types of problems shown in correlation with the children's relationships with others reveals that, according to the elementary school teacher's 
evaluation, the children who are considered leaders or popular with others present fewer problems of all types except hablt problems than children reported to "get along alright" or "disliked". Fourteen children, "leaders", or "popular", presented a total of fifty-five problems. Twelve children, who "got alone alright" or were "disliked" presented a total of ninety-eight problems.

\section{Types of Problems}

The types of problems as they were recorded in Nursery School are shown in Table 19. They were divided into the three groups as: aggressive, withdrawing, and habit problems. This classification was made because (1) these three groups are easier to handle than the many unclassified problens, and (2) this division seems a natural one as these three types of problems manifest themselves in distinetly different ways. People have come to think of those children with withdrawing behavior as being "good", and children behaving aggressively are labelled as "bad". However, in some cases, there is a relationship between the two in that undesirable ageressive behavior is used by individuals to cover up their fundamental feelines of insecurity. I It appeared that habit problems do not occur consistently in either aggressive or shy individuals.

$I_{\text {Wickman, Op. Cit. }}$ p.40. 
Table 20 lists the types of problems as reported displayed by the children in elementary school by their teachers. The list of problems in elementary school is different from the list in Nursery School because (1) the children's problems are not the same at ages seven and one-half to eleven as they were at three and four, and (2) the elementary school teacher ordinarily does not know of all of the problems that the Nursery school teacher knew about - for example - eating and sleeping habits, enuresis, sibling rivalry, and parent-child relationship problems.

The list in Table 20 of elementary school problems differs somewhat from the problems listed on the schedule ${ }^{1}$ as (1) some characteristics, not problems, of behavior such as being friendly, truthful, polite, having few or many friends, being interested in school work were found to be meaningless in the study. The teachers considered all twenty-six children to be friendly, truthful, and all except one to be polite. When the children were thought to be unhappy, that was noted in the group of withdrawing problems, and the one rude child was considered in the aggressive group. (2) Teachers did not respond at all to some of the problems on the schedule - dis-honest, steal, obscene behavior, sissy or tomboy, and response to opposite sex. (3) The habit problems, tics, speech difficulties, and nail biting were not included on the schedule, but were recorded as they were brought out by the teacher.

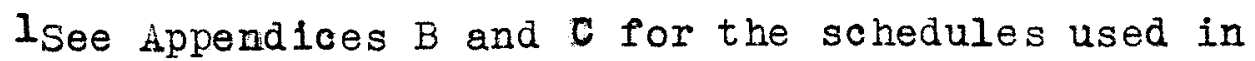
the study. 
TABLE 19

TYPES OF FROBLEMS OF TWENTY-SIX CHILDREN ATTENDING NURSERY SCHOOL, 1939-1942

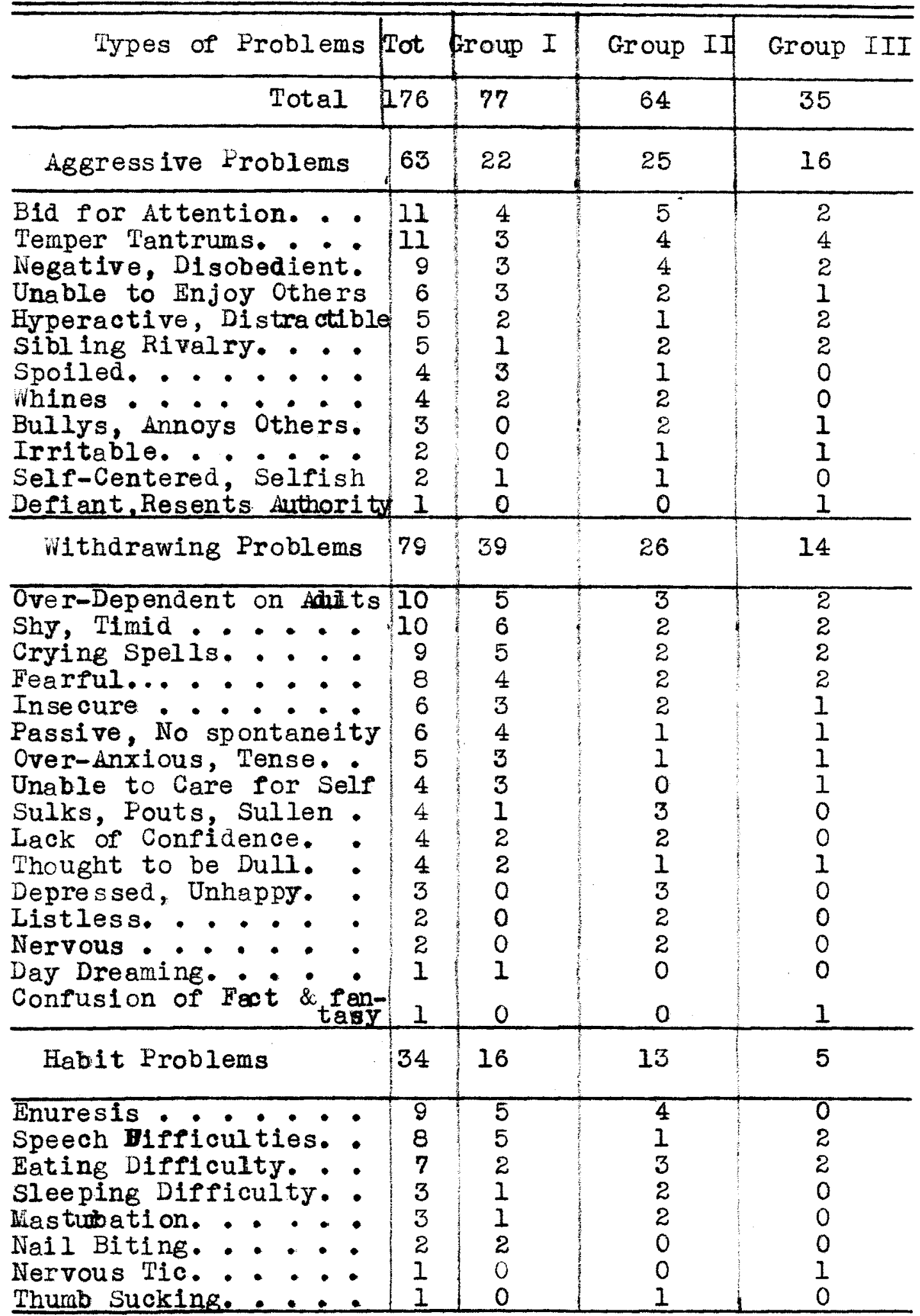


TABLE 20

TYPAS OF PROBLEMS CF TWENTY-SIX CHILDREN IN ELEMENTARY SCHOOLS, RLA-JUNE, 1946

\begin{tabular}{|c|c|c|c|c|}
\hline Types of Problems & Tot & Group I & Group II & Group III \\
\hline Total. & 153 & 40 & 69 & 44 \\
\hline Behavior in Class & 32 & 11 & 16 & 6 \\
\hline $\begin{array}{l}\text { Careless in Work: } \\
\text { Inattentive. } \\
\text { Failure to study : } \\
\text { Meticulous : : : }\end{array}$ & $\begin{array}{r}11 \\
10 \\
7 \\
4\end{array}$ & $\begin{array}{l}3 \\
2 \\
2 \\
4\end{array}$ & $\begin{array}{l}5 \\
6 \\
4 \\
0\end{array}$ & $\begin{array}{l}3 \\
2 \\
1 \\
0\end{array}$ \\
\hline Aggressive Behavior & 67 & 11 & 32 & 24 \\
\hline 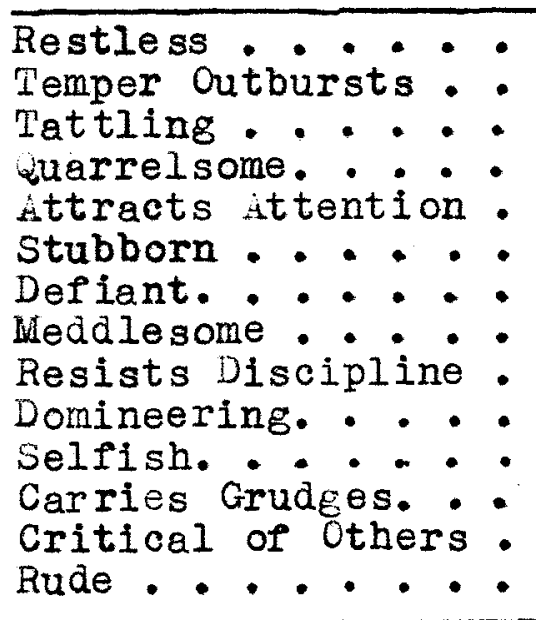 & $\begin{array}{r}17 \\
9 \\
7 \\
7 \\
6 \\
5 \\
4 \\
3 \\
2 \\
2 \\
2 \\
1 \\
1 \\
1\end{array}$ & $\begin{array}{l}6 \\
0 \\
2 \\
1 \\
0 \\
0 \\
0 \\
1 \\
0 \\
1 \\
0 \\
0 \\
0 \\
0\end{array}$ & $\begin{array}{l}4 \\
4 \\
3 \\
3 \\
4 \\
3 \\
3 \\
2 \\
2 \\
0 \\
1 \\
1 \\
1 \\
1\end{array}$ & $\begin{array}{l}7 \\
5 \\
2 \\
3 \\
2 \\
2 \\
1 \\
0 \\
0 \\
1 \\
1 \\
0 \\
0 \\
0\end{array}$ \\
\hline Withdrawing Behavior & 44 & 12 & 21 & 11 \\
\hline $\begin{array}{l}\text { Shy and Withdrawing. } \\
\text { Day and Dreaming : } \\
\text { Sulky or Sullen. } \\
\text { Cowardiy or Fearful: } \\
\text { Discouraged Easily: } \\
\text { Over-sensitive: } \\
\text { Cries Easily : } \\
\text { Unhappy. }\end{array}$ & $\begin{array}{l}9 \\
8 \\
7 \\
5 \\
5 \\
5 \\
3 \\
2\end{array}$ & $\begin{array}{l}5 \\
2 \\
1 \\
2 \\
0 \\
0 \\
2 \\
0\end{array}$ & $\begin{array}{l}2 \\
5 \\
4 \\
2 \\
3 \\
3 \\
1 \\
1\end{array}$ & $\begin{array}{l}2 \\
1 \\
2 \\
1 \\
2 \\
2 \\
0 \\
1\end{array}$ \\
\hline Habit Problems & 10 & 6 & 1 & 3 \\
\hline $\begin{array}{l}\text { Speech Difficulty }: \\
\text { Nail Biting: } \\
\text { Nervous } \\
\text { Enuresis : }: \\
\text { Masturbation : }:\end{array}$ & $\begin{array}{l}3 \\
3 \\
2 \\
1 \\
1\end{array}$ & $\begin{array}{l}1 \\
3 \\
0 \\
1 \\
1\end{array}$ & $\begin{array}{l}0 \\
0 \\
1 \\
0 \\
0\end{array}$ & $\begin{array}{l}2 \\
0 \\
1 \\
0 \\
0\end{array}$ \\
\hline
\end{tabular}


In a comparison of Table 19 and Table 20, it appears that, al though they are termed differently, the lists of aggressive behavior and habit problems cover much the same problems. The problem, "restless", as used in the study in elementary school was interpreted by the teachers to mean "hyperactivity" - Mioves arms and legs constantly" or "Can't sit still". That accounts for its being considered an aggressive problem rather than a withdrawing one as is "nervous" on the Nursery school list of problems. However, there is a noticeable lack of witharawing problems on the elementary school list. The major ones that do not appear in any form are: "over-dependence on adults", "insecure" or "lack of confidence", and "passive". This absence of these problems could be due to one or both of the followine reasons - the problems did not appear on the schedule, or the fact that these are forms of behavior that are not considered to be problems by teachers. It is unfortunate that they did not appear on the schedule so thet we could see with what frequency they were noted by the elementary school teachers.

It $c$ an be seen by looking at Table 20, that although withdrawing problems are not as well represented on the list as are the aggressive problems, that the types of behavior commented upon most frequently by elementary school teachers, are: (1) behavior in class work, (2) aggressive behavior, and last, (3) withdrawine behavior. 
This is understandable when we consider that the teacher's function is to aid educational achievement. Thus, her me in concern in the children's behavior is (1) whether or not they conform to classroom rules and routine and meet school work requirements. (2) Her second emphasis is on the problems which are expressed in overt and directly annoying behavior, and (3) her least concern is with the inner enotional conflicts of children which do not interfere directly with the purposes of teaching.

In Wickman's study, mental hygienists rated withdrawing problems more serious than aggressive problems. This fact is borne out in Table 19 which shows that, at Nursery School, withdrawing problems were reported with the most frequency.

In a discussion of the teachers' attitudes toward the behavior of the children in elementary school, we consider it worth mentioning that teachers reportad no cases of stealing, dishonesty, or any sex behavior. One teacher observed masturbation in these children. We are, therefore, unable to $\mathrm{s}$ ay whether there is no occurrenae of the se particular problems in this group of children; or whether the teacher's attitude toward these problems might have been the cause of her not noticing or discussing them. The teacher's attitude could play a large part in the results of the study insofar as her personal reaction to the child affects her evaluation of his behavior. The 
teachers throughout the study, when asked for a general reaction to the student, usually stated whether or not she considered the child to be a good student, a "lovely" or "nice" child, a difficult child to have in the room, or some other personal observation regarding the child. The teachers of the twelve children considered to be problems in elementary school reported the following general reactions to the children: Four made no comment as to their personal reaction, three said the child was "likeable", two said that the child was likeable as an individual, but did not fit into the group", one said, "I like the twins, but favor George of the two as he is less of a problem", and another said, "I like her, but she gets on my nerves".

Table 21 shows the number of children as they were considered by their Nursery School and elementary school teachers to show aggressive or withdrawing behavior.

\section{TABLE 21}

TYPE OF BEIAVIOR OF TWENTY-SIX CHILDR IN IN NURSERY SCHOOL, 1939-1942, AND IN ELIMENT ARY SCHOOL, 1946

\begin{tabular}{|c|c|c|c|c|c|c|c|c|c|}
\hline \multirow{2}{*}{\multicolumn{2}{|c|}{ Type of Behavior }} & \multirow[t]{2}{*}{ Tot } & \multicolumn{3}{|c|}{ Nursery School } & \multirow[t]{2}{*}{ Tot } & \multicolumn{3}{|c|}{ Elementary } \\
\hline & & & $I$ & II & III & & $I$ & II & $\overline{I I I}$ \\
\hline & Total. & 26 & 12 & 7 & 7 & 26 & 12 & 7 & 7 \\
\hline $\begin{array}{l}\text { Aggressive. } \\
\text { Withdrawing }\end{array}$ & $\because \because \cdots$ & $\begin{array}{l}12 \\
14\end{array}$ & $\begin{array}{l}4 \\
8\end{array}$ & $\begin{array}{l}5 \\
2\end{array}$ & $\begin{array}{l}3 \\
4\end{array}$ & $\begin{array}{l}15 \\
11\end{array}$ & $\begin{array}{l}5 \\
7\end{array}$ & $\begin{array}{l}6 \\
1\end{array}$ & $\begin{array}{l}4 \\
3\end{array}$ \\
\hline
\end{tabular}

All but three children that were considered by Nursory School to show one or the other type of behavior were felt 
by their elementary school teacher to continue showing that type of behavior.

According to the type of behavior shown at Nursery School, seven of twelve of the children showing aggressive behavior are considered problems in elementary school. Five of fourteen of the withdrawing children are problems at the time of the follow-up study. Eight of fifteen of the children considered showing aggressive behavior in elementary schools are thought to be problems, as well as four of the eleven showing withdrawing behavior. According to Table 19 , it appears that the improved group had more withdrawing problems and less aggressive problems. Group I had a total of sixteen aggressive problems; Group II twenty-four, and Group III fifteen. In Table 20, Group II again showed more aggressive problems, thirty-two, Group I presented eleven and Group III, twenty-four.

Table 19 shows Group I had a total of forty-one withdrawing problems, Group II - twenty-one, and Group III twelve. At elementary school, Table 20, croup II presents more withdrawing problems than the other groups - twentyone, Group I - twelve, and Group II - eleven.

At Nursery School, Group I presented more habit problems, and continues with the greatest number of habit problems in elementary school. Table 19 shows Group I with sixteen habit problems, Group II presented twelve, 
and Group III presented four. In Table 20, Group I showed a total of six habit problems, Group II showed one, and Group III presented three.

In the comparative study of nursery school versus nonnursery school groups, it was found that a larger number of nursery school children than of control-group children showed improvement in their habit status. "They eliminated a greater number of undesirable habits and more habits which indicate a lack of independence; and, on the other hand, they acquired a greater number of "desirable" habits and those indicating emancipation from adults. "I Habits as used here should not be confused with our classification of "habit problems". Habits in this comparative study refers to all forms of behavior that the child presents.

We would like to mention as a final thought in our follow-up of this group of Nursery school children that, as Ethel Kawin said of her study, "Those who are in contact with children attending nursery schools see many individuals where the benefits of nursery school experience seem quite obvious to the observer interested in a particular child. Until some method for measuring the development of personality as a whole has been formulated, studies such as this cannot attempt to evaluate nursery school experience for the individual child."2

1Kawin, op. Cit., p.50. 2Ibia., p.50. 
SURMMARY 
SURMLARY

Since the objective data of the study are too meagre to justify any real conolusions, the following summary is presented of our findings in this study which compares the behavior of twenty-six children in Nursery School, 1939 1942, with their behavior in elementary schools, 1946.

1. Unfarorable home situations were recorded more frequently for the unimproved group in Nursery School and for the problem in elementary school.

2. Children whose families were known more frequently to Social Service Exchange tended to show less Improvement in Nursery School than children with inPrequent registrations. The frequency of Social Service Exchange registrations was found to have no relation with the number of problems that the children presented at elementary school.

3. Five of six broken homes in the eroup produced problem children in elementary schools. Three were considered well-adjusted and three poorly adjusted at Nursery School. 
4. The children were distributed fairly evenly among the three groups of improvement at Nursery School according to the socio-economic level of their families. Nore children ( 8 of 10 ) from poor or dependent homes are considered to be problems than the children ( 3 of 10) from comfortable homes. The children from poor and dependent homes showed more aggressive problems, more withdrawing problems, and more classroom problems than the chilaren from average or comfortable homes.

5. The boys ap peared to show more problems than girls. There was an even distribution (thirteen boys and thirteen girls) as to sex in the group studied. Wore males (8) than females (6) were in the group of fourteen showing doubtful improvement in Nursery School. Five males and seven females were in the improved group. Seven boys showing a total of 87 problems and five girls showing a total of 66 problems were considered problems in elementary school.

6. More only and youngest children were in the improved group than the oldest and the middle child. However, only and youngest children are not making any better adjustment at elementary school than are the oldest and midale children. 
7. No relation was found between the age of the children in el ementary school or Nursery School and the number of problems shown.

8. With the teacher's evaluation of the child's physical condition as a basis, it was found that none of the children classified as being in good physical condition were considered to be problems in elementary school. There were no children considered in poor health in the improved group of children in either Nursery school or elementary school.

9. In the improved group at Nursery school, three children (of 8) had IQ's below 100; four (of 9) had IQ's from 100 - 119; and five (of 9) had IQ's of 120 and over.

The greatest number of problem children (5) in elementary school came from the group with an $I_{Q}$ level of below 100. The next number (4) came from the group with IQ's of 120 and over. The least number of problem children (3) were found in the group with Ie's of $100-119$.

10. All of the chilaren (4) making low grades at elementary school were considered to be problems. Seven (of 17) making average grades were problems, and one (of 5) making above-average grades was a problem. 
11. Two-thirds of the twenty-six children attending Nursery School for four months or less are problems in elementary school. Two-fifths of the children attending more than four months are problems.

12. The children considered to be popular or leaders showed more improvement in Nursery school and showed a better adjustment at elementary school than the children considered to be disliked or to "get along glright".

13. All but three children considered to show either aggressive or withdrawing behavior in Nursery school were reported by elementary school teachers to continue showing the same type of behavior.

14. Children showing aggressive behavior in elementary school are considered to show more problems than those showing withdrawing behavior. Eight (of 15) children showing aggressive behavior in elementary schools are thought to be problems; four (of 11) children showing witharawing behavior are thought to be problems.

15. In both Nursery School and elementary school, the unimproved group showed more aggressive problems. At Nursery School, the improved group presented a greater number of withdrawing problems. In elementary school, the unimproved group presented more 
withdrawing problems. The improved group presented more habit problems in both Nursery School and ele-mentary school.

16. The elementary school teachers reported with greater frequency (1) problems of classroom difficulty, next, (2) aggressive problems, next, (3) withdrawing problems, and last, (4) habit problems. The ivursery School teacher reported (1) withdrawing problems more frequently than (2) aggressive problems, and with least frequency, (3) habit problems.

17. Seven children were felt to have shown little or no improvement; flve of these are still considered to show many problems at elementary school. Seven children were felt to show doubtful improvement at Nursery School and three of these are considered problems in elementary school. Four of twelve children felt to show improvement at Nursery School are considered problems in elementary school.

18. Eight, or two-thirds of the children considered to be problems in schools in 1946 ogme from the two groups that showed doubtful improvement at Nursery School. 
BIBLIOGRAPHY 


\section{BIBLIOGRAPHY}

\section{Books}

Ackerson, Luton. Children's Behavior Problems. Chicago: The Univer sity of Chicago Press, 1931.

Adler, Alfred. The Education of Children. Translated by Eleonore and Fredriech Hensen. New York: Greenberg, 1930 .

Bassett, Clara. The School and ivental Health. New York: The Commonwealth Fund, 1931.

Blatz, William E., Millichamp, Dorothy, and Fletcher, Wargaret. Nursery Education, Theory and Practice. New York: T. Korrow and Co., 1935.

De Lima, Agnes. Our inemy the Child. New York: New Republic, Inc., 1925.

Gessell, A.I. and others. First Five Years of Life. New York: Harper, 1940.

Infant and Child in the Culture of Today. New York: Harper, 1943 .

Goodenough, Florence I. and Anderson, John E. Experimental Child Study. New York: The Century Co., 1931.

Isaacs, Susan. The Nursery Years. New York: Harcourt, 1831.

- Social Development in Young Children. New York: Harcart, 1933.

Johns on, Harriet M. Children in the Nursery School. New York: The John Day Company, 1930.

Kawin, Ethel and Hoefer, Carolym. A Comparative Study of a Nursery School Versus a Non-Wursery School Group. Chicago: The University of Chicaeo Press, 1931. 
Leonard, Edith M., Miles, Lillian, and Jan der Kar, Catherine. The Child at Home and School. New York: American Book Company, 1942.

Paynter, Richard H. and Blanchard, Phyllis. A Study of Educational Achiovement of Problem Children. New York: The Commonweal th Fund, 1929.

Richards, Esther Loring. Behavior Aspects of Child Conduct. New York: The liachililian Company, 1932.

Wickman, E. Koster. Children's Behavior and Teachers' Attitudes. New York: The Commonwealth Fund, 1929.

\section{Articles}

Ackerly, Spafford and Mellor, Ruth. "The Value of a Nursery School in a Psychiatric Set-Up", American Journal of Orthopsychiatry, XI, (January, 1941), 172-175.

Anderson, Farold H. "The Relationship of Nursery Schools to Public Educ ation", Mental Hygiene, XVII, 1939, $442-451$.

Argel, Samuel Z. "Bringing Up Children", Wental Hygiene, XXI, (July, 1937), 436-451.

Beckman, J. William. "The Opportunity Class: A study of Chilaren With Problems", American Journal of Crthopsychiatry, KIV, (January, 1944), 113-125.

Cox, Grace and Anderson, Harold. "A Study of Teachers' Responses to Problem Situations in school as Reported by Teachers and Students", American Journal of Orthopsychiatry, XIV, (July, 1944), 528-544.

Ebaugh, Franklin G. "Psychiatry in the Care of Children", Mental Hyglene, XXIX, 1935, 223-237.

Finley, Halcolm H. "The Classroom as a Social Group", American Journal of Orthopsychiatry, XI (January, 1941) $21-33$.

Fowler, Burton P. "The Child As Affected by the Family", Mental Hysiene, XVIII, 1934, 431-441. 
Kriegman, George and Hilgard, Josephine. "Intelligence Level and Psychotherapy with Problem Children", American Journal of Orthopsychiatry, XIV, (April,1944) $251-266$.

Newell, H. W. "The kiethods of Child Guidance Adapted to a Public School Program", hental Hygiene, XVIII, $(1934), 362-372$.

Pisula, Cecila. "Behavior Problems of Children from High and Low Soc io-Economic Groups", Mental Hygiene, XXI, (July, 1937), 452-455.

Veo, Louise and Woodward, Luther. "Planned Social Work in the School", American Journal of Orthopsychiatry, XI, (January, 1941), 1-14.

Wile, Ira s. "Integration of the child the coal of the Educ ational Program", Mental Hygiene, XX, 1936, 249-261.

\section{Unpublished Material}

Louisville Health Council. "Report on the Mental Hygiene Clinic Nursery School". Unpublished report to the Community Chest, Louisville, Ky., June, 1942. (Mimeographed)

Mierrifield, Mildred and Warson, Frances. "Studies of the Mentel Hygiene Clinic Nursery School Children". Unpublished reports made December, 1940; May, 1941; and June, 1942; Loui sville, Ky.

"Nursery School Division", Functions of the Louisville Mental Hygiene Clinic and Department of Psychiatry. Report compiled by a special committee from the Board of Directors of the Mental Hygiene Clinie, Louisville, $\mathrm{Ky}$., 1940.

O'Brien, Mary Elizabeth. "History and Development of the Mient al Hyglene Clinic". Unpublished Master's thesis, Graduate Division of Social Administration, University of Loulsville, 1944.

Sawyer, Nirs. A. B., Jr. "The Nursery School", Louisville, Ky., September, 1939. (Mimeographed) 
APPENDIX 
APPENDIX A

Summary of the Follow-Up Studies Made on the Mental Hygiene Clinic Nursery School Children, December, 1940; Hay, 1941; and June, 1942 By Psychiatric Social Workers

At the beginning of the child's enrollment in Nursery School and during the year, the mothers, in most cases, had discussed with some nember of the staff their child's problems. The plan for working with the mothers was very flexible and depended upon the seriousness of her problem. The aim of these interviews with the mothers was to help them with $a$ better understanding of the child's difficulties and his personality needs. This type of case work varied occasionally with the particular mother and covered things such as a simple arrangement for the physical examination of the child through concrete suggestions regarding his training in routine habits to a consideration of more serious problems in the home of marital relationships. These aifferent types of problems were found which appeared to have a direct effect on the behavior of the child:

Over-anxiety regarding child's behavior; rejecting, punishing attitude toward child; rigid, meticulous, over-demandine; lack of consistent and firm discipline; poor physical health of mother; difficulty in accepting responsibility for maternal role; limited intelligence, unstable marital situation; inability to handle guilt and anxiety re own negative feelings toward child; 
lack of confidence in handine child; mild mental depression; complete absorption in child for own satisfaction; inability to give child adequate love and affection; extreme nervousness; strong need for child's dependency; and conflict between parents re discipline.

In some instances, the child was seen in the clinic merely for diagnosis and was not considered a serious enough problem to return. In other instances, the child was turned over to a social worker for therapy. Some few children were seen neither by psychiatrist nor social worker because they did not come to school lone enough, or because of some circumstance concerning that particular child.

The measurement of improvement is naturally very difficult with anything as intangible as human behavior and feelings. In general, most children show improvement quickly in Nursery School, but it has been found to be true that their progress is of ten impeded by the mothers' resistance to change. In some instances, when the children continued in school for a long period of time, they were able to carry over much of their progress and change into the home, al though the parents did not change. Where the problem was more serious, real progress at home resulted only when the parent was able to change.

In a consideration of what happened to these children, their gains while in Nursery School and while social work service was being given to their mothers, are seen as follows: 
More Independence, self-rellance; less dependence on others for entertainment; better relationship with other children; more positive relationship with parents; more spontaneous, outgoing; better acceptance of routine; more obedient, easier for mothers to cope with; developed leadership capacity; ability to express self; improved eatine habits, speech, and general health; disappearance of temper tantrums, nervous tic, enuresis, and masturbation; less negativism and aggression; lessening of fears, gain in self-confidence; less nervousness and distractibility; and more ability to share and give.

In terms of gains shown by the mother, it is not possible to evaluate this as clearly in terms of specific problems. In general, one of the gains noticed most frequently was the lessening or disappearance of much of the mother's anxiety over the child. Another big gain occurred In those situations where there was faulty handing of the child"s routine life, mostly due to the mother's lack of knowledge, and where suggestions of concrete things to do could be given the mother. The least gain appeared in those situations where the mothers showed a rigid personality, were over-particular, fussy, and meticulous. In these cases, the child's problem appeared directly related to the mother's personality patterns and to have accomplished more than superficial improvement would have necessitated far-reaching changes in the nother.

A total of 58 out of 79 children were studied at least once in a follow-up. we had observed the children during the school year, but we were anxious to learn just what had become of each chlld's problems after the close 
of Nursery School. Calls were made at the home and school of the child in December, 1940; Kay, 1941; and June, 1942.

The mothers seemed to welcome this follow-up visit and were frank and free in their discussions of the various problems of their particular child. We were interested in whether the problems had disappeared, improved, or remained unchanged. Children who were patients from Children's Free Hospital and those children who attended less than two weeks were omitted from the study.

From al 1 these studies, a few significant generalizations are evident:

1. The majority of children showed a quick improvement in the ir problems after entering Nursery School.

2. Not more than two children in any of the three groups failed to improve during their Nursery School experience.

3. When possible during the past two school years, mothers were given help with their children's problems. It has been found that the degree of improvement of the children at home has been commensurate with the mothers" ability to cooperate in treatment and desire to make a real change in themselves as well as the children.

4. In the follow-up of the two groups out of Nursery School for a year or more (30 children in all), it was found that three in the first group and one in the second, or 13 per cent were making an unsatisfactory adjustment in school. Only 3 of these 4 were a problem at home. 
APP ENDIX B

NURSERY SCHOOL RECORD

Name

Sex Birthdate

Address

Control-study Group

Date of Entry

Age at Entry

Term of Stay

Referral Source

Parent's Marital Status (H-D-S-W)

Contact with Parent Teacher Social Worker

Outstanding Features in Home Situation

Social Agency Clearings

Physical Condition (IIInesses, Personal Appearance, Physical Activity, Examinations)

Psychological Tests (Dates - Scores)

At tendance

Activities Child Performed Best

Least Best

Adjustment (Good - Average - Bad)

Teacher's General Reaction

Other Children's Reaction

Major Behavior Difficulties

Any Marked Improvement 
INTERVIEW WITH TEACHER

Name

Address

Attended Other Schools

Grade at time of study

Contact with parents

Teacher

Visiting Teacher
Sex Birthdate Control-Study Group

Social Agency Clearings

Outstanding Features in the Home Situation

Marital Status: $\mathbb{M}-D-S-W$

Physical Condition (Illnesses, Personal Appearance, Physical Activity, Examinations)

Psychological or Achievement Tests

Attendance

Subjects Performed Best (Oral - Written - Creative)

Least Best

Grades (Good - Áverage - Bad)

Teacher's General Reaction

Other Children's Reaction

Social Behavior:

Inattentive

Careless in Work

Niet1culous

Conformity to Discipline (Compliant

Attract attention

or Resisting)

Carry grudges

Domine ering

Querrel some

Stubborn

Defiant

Dishonest

Steal

Obscene Behavior

Miasturbation

Enuresis

Selfish

Friendly

Restless

Temper Outbursts

Tattling
Failure to study

Interested in work

Dishone st in Classwork

Day Dreaming

Shy and withdrawing

Oversensitive

Truthful

Critical of Others

Mieddle some

Sulky or sullen

Courage ous or bold

Cowardly or fearful

Happy

Polite or rude

Discouraged easily

sissy or tomboy

Wany friends

Few close friends

Response to opposite sex 